\title{
ÇOĞULCU KAMUSAL ALANDA DINI KIMLIKLERIN ÖZGÜRLÜĞÜ VE DEMOKRASi ILETIŞiMi
}

\section{Ali DEMiR*}

Gönderim Tarihi: 01.03.2021- Kabul Tarihi: 24.03.2021

Demir, A. (2021). “Çoğulcu kamusal alanda dini kimliklerin özgürlüğü ve demokrasi iletişimi”. Etkileşim, 7, 98-127. doi: 10.32739/etkilesim.2021.7.120

Bu çalışma araştırma ve yayın etiğine uygun olarak gerçekleştirilmiştir.

\section{Öz}

Çoğulcu kamu alanı bir yandan eylem, çıkar ve kimlikler gibi sosyolojik kategorilerin, öte yandan özgürlük, demokrasi, farklılık ve eşitlik gibi felsefenin temel kavramlarının birbiriyle iletişime geçtiği yerdir. Buradaki iletişim tarihsel olarak kişilik ve kimliklerle hep etkileşim içindeydi. Zamanla farklılık veya eşitlik üzerine kurulu toplumsal aidiyetlerin kamudaki iletişimi, kimi çatışmaları da beraberinde getirdi. Thomas Hobbes, Immanuel Kant ve Jürgen Habermas gibi düşünürler kamudaki iletişimsizlikleri çoğulculuk kavramıyla işlediler. Çoğulculuk tarihsel ve sosyolojik olarak dini kimliklerle ilintilidir. Makalede bu ilinti, iletişim, etkileşim ve ilişki ağları Gılgamış'taki Tanrı imajı, Emile Durkheim'ın dine yüklediği işlev ve de kimi sosyolojik örnekleriyle işlenecektir.

Anahtar Kelimeler: kamusal alan, eşitlik, demokrasi, iletişim, dini kimlikler. 


\title{
FREEDOM AND DEMOCRACY COMMUNICATION OF RELIGIOUS IDENTITIES IN THE PLURALISTIC PUBLIC SPHERE
}

\author{
Ali DEMiR*
}

Received: 01.03.2021- Accepted: 24.03.2021

Demir, A. (2021). “Çoğulcu kamusal alanda dini kimliklerin özgürlüğü ve demokrasi iletişimi”. Etkileşim, 7, 98-127. doi: 10.32739/etkilesim.2021.7.120

This study complies with research and publication ethics.

\begin{abstract}
Pluralistic public sphere is where sociological categories such as action, interests and identities, and the basic concepts of philosophy such as freedom, democracy, equality and difference, are connected with each other. Communication here has always been in interaction with personalities and identities. However, in time, public communication of social belongings based on difference or equality has led to some conflicts. Thinkers such as Thomas Hobbes, Immanuel Kant and Jürgen Habermas have studied miscommunication in public within the framework of the concept of pluralism, which is historically and sociologically related to religious identities. In the article, this connection of communication, interaction and relationships will be covered by the image of God in Gilgamesh, the function that Emile Durkheim attributed to religion, and some sociological examples.
\end{abstract}

Keywords: public sphere, equality, freedom, communication, religious identities. 


\section{Giriş}

Bu yazıda demokrasi, özgürlük, kamusal alan, çoğulculuk, çıkar, laiklik, sekülarizm, ideoloji ve dini kimlikler gibi modern toplumsal yapıların temel iskeleti niteliğindeki kavramlar iletişim kavramı ekseninde tartışılmaktadır. iletişim, bütün bireylerin birbirleriyle kurdukları yüz yüze etkileşim, ilişki ve de söylemi içermesinin yanı sıra örgütlerin, kurumların ve toplumların hem birbirlerini hem de üyeleri konumundaki bireylerin eylemlerini etkileme, sınırlama ve yön verme eğilim alanını da kapsar. iletişim; sadece verilmek istenen mesajın sosyal ilişkiye, bilgiye veya güce dönüştürülmesi olarak değil, Niklas Luhmann'dan yola çıkarak en genel anlamıyla fiziki mekândan bağımsız oluşum, dönüşüm, gelişim ve aktarım dönemlerini de sarmalayan bir olgu anlamında kullanılmaktadır (1997: 70). iletişim; kurulmuş, kurulan veya kurulmak istenen her etkileşimi ve de bilinçli olarak istenen ya da istenmeyen her ilişkiyi kapsar. İletişimin sosyal ilintiye, ilişkiye, birlikteliğe, karara, bilgiye veya sosyal başarıya dönüşebilmesi ve/veya dönüştürülebilmesi için konuşma dili, yazı, sayı ve dijital sistem gibi araçlar gereklidir. Luhmann para, fonksiyon, yapı, kurum ve onaylanmayı (Selbstvalidierung) toplumda sembolik olarak da en çok genelleştirilmiş taşıyıcıları, bu anlamıyla araçların başında sayar (1997: 190-202). iletişim bu çalışmada, Luhmann'ın 'sistem teorisi' merceğini de kapsayacak şekilde, toplumdaki bağlayıcı normlarla ve/veya sistemsel taşıyıcıların koordinasyonuyla, olay ve olguları etkileşime, ilişkiye, dönüşüme, değişime vb. mani olan etkin ağ olarak ele alınmaktadır. iletişim kavramı odaklı bu genel girişin ardından bu yazıya temel oluşturacak özgürlük, demokrasi, çıkar ve kamusal alan gibi kavramlar üzerinde durmakta fayda vardır.

\section{Teorik Belirlemeler: Özgürlük, Demokrasi, Çıkarlar ve Kamusal Alan}

Bu alt başlıkla öncelikle iletişim ve eylem kavramları arasındaki yakınlığı göstermek hedeflenmektedir. iki kavram arasındaki yakınlık, bu yakınlığın iletimi ve yakınlık iletim ağının özgürlük ve demokrasiyle olan ilişkisi sosyal bilimler ve (siyaset) felsefesinin temel konularından biridir. Özgürlük öncelikle bireysel düzlemde etkin ve normatif bir kavram iken, demokrasi başından beri, bir toplumsal etik yapı ve/veya hukuk çerçevesinde birlikte karar oluşturma mekanizması olarak belirlenmiştir (Sartori, 1997; Cheneval, 2015). Demokrasi eski Yunancanın demo kelimesinden türetilmiş ve halk, yani karar veren merci demektir. Bununla birlikte o dönemde demo sadece polis'i, polis'te yaşayan halkı kastederken, bugün bu teklik demo'leşti, çoğullaştı ve parlamento, anayasal düzen, bölgesel özerklikler, büyük şehir belediyeleri ve de kimi zaman meşrulukları demo'dan değil ama onun meşru hukukuyla sağlanmış çok uluslu holdingler ${ }^{1}$ gibi kurum ve mercileri de kapsar duruma geldi (Cheneval ve Schimmelfennig, 2013). Örneğin, Yunan filozoflarından Aristoteles halk kavra-

Facebook ve Twitter'ın Amerika Birleşik Devletleri başkanı Donald J. Trump'ın mesajlarını "haklı" olarak, yani hukuki nedenlerle silmeleri bu tip meşruluğa bir örnek teşkil ediyor.

$100 \mid$ ETKileşim | Yıl 4 |Sayı 7 |Nisan 2021 
mını polis'e aidiyete ve de bu grubun özgürlüğe ulaşabilme erdeminde aradı. Aristoteles ve dönemin önemli felsefe akımı olan stuacılık özgürlüğü evrensel bir gerçek olarak algılanan mutluluğa erişme istemi (eudaimonia) savından türetti (Aristoteles, 1909: 127-129). O'na göre eudaimonia bütün insanların ortak amacıydı. Ancak eudaimonia sadece polis'te yaşayan özgür bireylerin ulaşabileceği bir amaçtı. Bu çerçevede Aristoteles'e göre polis, eşit ve özgür bireylerin ortak kullanım alanıydı. Günlük zaruri ihtiyaçlarını karşılamak için bizzat kendi iş gücünü, emeğini kollanmak zorunda kalmamak polise aidiyeti belirleyen etmendi. Buna karşılık biyolojik ihtiyaçlarını karşılamak için çalışan ve yaşayan barbarların, kadınların ve kölelerin polis'in kamusal alanında temsil olanakları olamazdı. Onların yeri oikos (ev) sınırları içerisinde kalırdı. Bu iki alan arasında kesin, keskin sınırlar vardı (Arendt, 1992: 33-40). Tam da bu uyuşmazlıktan dolayı Aristoteles özgürlük kavramından, toplumsal düzlemde polis'e aidiyeti ve bireysel çapta ise çalışmak zorunda kalmamayı, zorda, zorunlulukta olmamayı ve de bu son anlamıyla barbarların, kadınların, kölelerin emeğini kamulaştırabilme erkini anlıyordu.

Eudaimonia Marcus Aurelius tarafından bütün elitlere örnek teşkil eden bir yaşam biçimi olarak önerildi. Tek tanrılı dinlerin ortaya çıkışılla eudaimonia anlayışının prensipte bütün sorunlara ve haksızlıklara rağmen gerektiğinde "kötülüğü de iyilikle karşıla" önerisine, bu içeriğiyle de "yaratana güven" fikrine evrildiğini iddia etmek mümkündür. Buradan günümüze gelirsek, özgürlüğü en azından sosyolojik olarak, yani somut ampirik verilere dayanarak bireyin ait olduğu toplumda çıkarlarını genelleştirebilme kabiliyeti olarak tanımlayabiliriz (Parsons, 1951: 37; 1960; 1968). Ancak soru "hangi bireyin, hangi çıkarı, hangi toplumda, nasıl genelleştirileceği" ile ilgilidir. Bu soru ise bizi, Max Weber'in 'eylemleri belirleyen fikirler değil, çıkarlardır' tezinden de yola çıkarak, özgürlüğün sadece düşünsel bir kavram değil ama kimi normların ışığında geliştirilen ancak son tahlilde kimi çıkarları korumanın eylem biçimi olduğunu da görmemiz gerekiyor (1920: 252).

Özgürlük, Amerika (1765) ve Fransız (1789) devrimleriyle ahlak felsefesinin ilerisinde eşitlik, kardeşlik ve adalet gibi sosyolojik ve felsefi kavramlarla anılmaya başlandı. Özellikle John Locke ve bugünkü takipçileri veya en azından ardılları olarak bilinen liberal demokratlar özgürlüğü son tahlilde bireyin yaşamını topluma, toplumun meşru gördüğü normlarına, etik yapısına rağmen de kendi istemi doğrultusunda idame edebilmesi olarak tanımladılar (Locke, 1997, Rawls, 1998: 12-23, 316-320). Buna karşılık Fransız Devrimi'nin fikir babalarından biri olarak bilinen J. J. Rousseau özgürlüğü, insanın ve/veya toplumların bizzat kendisinin koyduğu kurala istisnasız uyması olarak tanımladı (2003: 23). Ona göre özgürlük, bireyin kendisini otonom iradesiyle topluma katmasıdır. Rousseau özgürlük kavramında hem fikir ve çıkarları hem de birey ile toplumu bir arada düşündü. O Aristoteles ve Locke'den farklı olarak özgürlüğün altını içerik olarak zora tabi olmamakla değil de bireyin toplumla olan iletişiminde özel çıkarlardan bağımsız olmakla doldurmak istiyordu. Rousseau çıkar kavramını genel ve toplumsal istemler şeklinde ikiye ayırdıktan sonra, 
toplumsal çıkarlarla genel istemler arasındaki ilişkinin Yeni Çağ'da toplumun lehine kurumsallaştırıldığının altını çizdi (Rousseau, 1984: 255-258). Rousseau çıkarlarla özgürlükler arasındaki ilişkinin doğru anlaşılmasının ön koşulu olarak, çıkarların değil ama özgürlüklerin sosyal normlarla, ahlaki değerlerin bağlayıcılığı gücüyle yorumlanması gerektiğini savundu. Ona göre çıkarları, toplumun örgütsel yapılarında aldıkları kurumsal halleriyle incelemek gerekirdi. Bu ise çıkarları mutlaka sosyal-ekonomik kavramlarla anlamaya çalışmayı ve de değerlendirmeyi zorunlu kılar. Buna karşılık özgürlükleri bir yandan ahlaki, dini, etik ve hukuk anlayışlarının ışığında, diğer yandan da felsefenin dünyaya ve insana dair sunduğu kategorilerle yorumlamak mümkündü (Rousseau, 1984: 43-53). Rousseau bu ayrımla hem çıkarlar ve özgürlükler arasındaki ilişkiye dikkat çekmekte, hem de bu ikisinin, toplumun birlikte karar alma mekanizmaları olan demokrasiyle bağını ortaya koyarak, onun altyapısı olan hukuk, etik ve kültür gibi kurumlarla olan ilişkisini anlamaya ve anlatmaya çalışmaktadır.

Halkı, Rousseau'nun bu iletişimci anlayışıyla demokrasi ve özgürlük temelli fikir ve çıkar birlikteliğinin bir biçimi olarak tanımlayabiliriz. Bu evrimsel aşamaları da göz önüne aldığımızda ve demokrasiyi etik ve/veya hukuksal kimi normlardan yola çıkarak, halkın ve/veya kimi genel çıkarları korumak adına uzun erimde de doğru olma ihtimali yüksek olan kararları 'birlikte' alma mekanizması olarak tanımladığımızda, özgürlüğü bu mekanizmanın bireyin evrensel olma ihtimali olan normlarla sadece lehine çevirebilme, kendi genel çıkarlarınca yeniden düzenleme istemi değil ama bunun da ötesinde bu istemin toplumda kabul görmüş kurumların da desteğiyle, onların meşrulaştırma yetisini de kullanarak gerçekleş(tir)ebilme ihtimali olarak belirleyebiliriz. Bu saptamadan yola çıkıldığında demokrasiyle hukuk değil ama demokrasi ile (toplumsal) özgürlük arasında yapısal gerginliğin hep olduğunu ve bunun doğası gereği kendisini (çoğulcu) kamusal alanda kimliklerin, aidiyetlerin iletişimi aracılığıyla gösterdiğini tespit edebiliriz (Habermas, 1996: 128-154; 2013). Tarihsel olarak da bu aidiyetlerin başında tabii etik ve dini kimlikler gelir.

Kamudaki bu gerginliği bir yandan özgürlük, öte yandan toplumsal düzlemde aidiyetin ve bireysel bağlamda ise kişiliğin bileşenleri olan eşitlik ve farklılık kavramlarına bakarak incelemek mümkündür. Ancak eşitlik ve farklılık kavramlarına değinmeden önce kamu kavramına ilişkin şu üç tespiti yapmak gerekir: Öncelikle (çoğulcu) kamusal alan, özgürlük ve demokrasi kavramlarına göre hem daha yeni hem de tanımlanması daha zor bir kavramdır. Bu zorluğun bir nedeni kamusal alanın, özgürlük ve demokrasiyle olan organik ilişkisinin kültürel kodlanma biçimidir. Bu ilişki, iletişimi bireysel fikir ve eylemlerin ötesinde, kurumsal tercihler, aidiyetler, özgürlükler ve demokrasiyle ilintisi kuruldukça genişleyen, çoğullaşan ve keskin çizgilerle belirlenmesi zorlaşan kamusal alanın yapısıyla ilgilidir. Özgürlük, artık ne sadece negatif yönüyle, yani devlet zorunun olmadığı an, ne de toplumdan soyut bireysel bir tercih ya da kabiliyet olarak görülür. Bunların yerine özgürlük şimdilerde artık bireylerin kimlikleriyle, çıkarlar ve fikirlerini savunabildikleri kamusal otonomi olarak karşımıza çıkar (Habermas, 1996).

102 | ETKíleşim | Yıl 4 |Sayı 7 | Nisan 2021 
Yapmamız gereken ikinci tespit ise bu karmaşık ilişkiler ve iletişimler ağının, moderniteyle birlikte daha çetrefilli bir hal almaya başladığıdır. Moderniteyle, yani ekonomide modernleşme, anayasal düzen, liberal demokrasi ve bireysel otonomi üzerine kurulu toplumlara geçişle birlikte, kamusal alan bir yandan ahlaki, etik, dini ve felsefi fikirler ile ekonomik, sosyal, grupsal ve bireysel çıkarlar öte yandan da bunların demokrasi, özgürlükler ve kimliklerle olan iletişiminin vuku bulduğu ve de bütün bunların etrafından kendisini yeniden kuran sivil toplum ve diğer aktörlerin eylem yeri olmaya başladı (von Beyme, 1999; 2007: 87, 151, Habermas, 1981; 2013: 137-140). Moderniteyle birlikte teklik, aynılık, benzerlik bir yandan çoğulculuğa, farklılılara, eşitliğe, özgürlüğe, öte yandan da bunların etrafında toplumun meşru kurumlarca yeniden dizayn edilebilme ihtimaline evrildiler. Habermas işte bu tarihsel arka planı göz önüne alarak kamusal alanı özgür ifade ve eylem alanı olarak tanımlamaktadır (1992: 435).

Son olarak Habermas Kamusallı̆ın Yapısal Dönüşümü (Strukturwandel der Öffentlichkeit) kitabında, kamusal alanın sosyolojik ve tarihi evriminin yanı sıra bir taraftan aktörlerin özgürlük ve eşitlik istemleriyle, onların fikirleri ve çıkarlarıyla, diğer taraftan da bunların kurumları olarak gördüğü farklı ilinti, ilişki ve iletişim kanallarıyla kamu adına ve yeniden yapısal dönüşüme "zorlandığını" ele alır. Kamusal alan bu modelde, bireylerin ve çevrelerin aidiyetleriyle, çıkarlarını ve fikirlerini meşru araç ve amaçlarıyla iletişime, zora, yani devletin zor kullanımına dönüştürülmesi olarak işlendi. Habermas entelektüel yaşamının ilerleyen dönemlerinde toplumun genel istemlerini "devletin zorla dayatmasına dönüştürülme" modelini reddettiyse de, kamusal alan özellikle de siyaset alanının aktörleri tarafından artık sadece özgürlükçü fikirlerin değil fakat özgürlükçü zorun araçsal akılla da kurumsallaştırılmasının alanı olarak da görülmeye başlandı (2013: 21). Oysa Habermas bireyden ve toplumdan kopuk ve de bireyci eylemi değil ama bizzat toplumun bir üyesi olarak ve bu özelliğiyle hem toplum tarafından ona sunulan hem de bizzat kendi özgür iradesiyle edindiği, seçtiği ve de istediği kimliğiyle kamusal alanda ve kamu adına iletişimsel eylemi bekliyordu. Bu bireyin iletişim motifini araçsal akıl değil ama iletişimsel eylem belirler.

\section{Eşitlik ve Farklılık}

Şimdi özgürlüğün, kişiliğin ve aidiyetin bileşenleri olarak belirlediğimiz eşitlik ve farklılık kavramlarını açıklamaya şu tespitle başlayabiliriz: bir, I, one, 1, eins ve ju aynı iki, Hasan Sağol, Hasan Demir, Hasan Korkmazgil "aynı" isimleri taşıyan, "benzer" özelliklere sahip "farklı" kişiler. Buradan bakıldığında varlık, varlık üzerine kurulu kişilik kavramı felsefenin bir yöntem biçimi olan mantıkta önemli fonksiyonu olan bir yüklem. Onunla bir şey ya diğer bütün objelerden ayrıştırılır ya da diğer bütün objelerle aynı olduğu tespit edilir. Felsefe, daha doğrusu mantık bilimi bu tespiti kişilik kavramına herhangi bir üstünlük, süreklilik ya da kalite atfetmeksizin yapar. Yani sürekli değişken, hiçbir önemli, belir- 
gin özelliği olmayan ve hiç kimse tarafından beğenilmeyen bir şey ya da ikide bir fikrini, tavrını, kararlarını, özelliklerini, taraftarlıklarını ve yaşam biçimini değiştiren kişide formel olarak, formel mantığa göre bir kişiliğe, kendisiyle aynı olma özelliğine sahip (Heinrich, 1979: 135; Habermas, 1981: 159).

Bununla beraber hayat alanında ne varlık, kişilik, aidiyet, benzerlik, farklılık, eşitlik ne de ahlak, etik, demokrasi ve hukuk formel mantıktan yola çıkılarak anlaşılabilir konulardır. Bunların özellikleri ve anlamları hem zamanla ve hem de toplumdan topluma değişir. Bunları Karl Popper'in bilim anlayışıyla ne yanlışlayabiliriz (falsifize) ne de doğrulayabiliriz (verifize) (Popper, 1995). Bu anlamıyla onlara dair gerçeklikleri yine Popper'le değiştirilemez doğa yasaları değil ama izafi kararlar olarak değerlendirmek gerek (Popper, 1992: 77). Diğer bir söylemle, biz onları hem anlayabilir, anlatabilir, onlara uyabilir, onlara uymadığımızda cezalandırılabiliriz hem de onların zaman içinde değiştiğini bilerek, onlara göre bir yaşam biçimi kurabiliriz veya bilerek, isteyerek kurmaktan vazgeçebiliriz. Örneğin farklılı modernite öncesi toplumlarda ahlak, din veya kan bağı ilişkisi üzerinden tanımlanır ve 'Tanrının bir lütfu' olarak görülürken, günümüzde farklılık biyolojik vasıflar ve ilahi belirlemelerden çok tarihsel olgularla ve onlara dayanılarak verilen kararlar üzerinden açıklanır. Bu yüzden farklıık, eşitlik kavramıyla anılır oldu. Hasan diğer bütün insanlarla insan olma vasfından dolayı "benzer", içerisinde toplumsallaştığı toplumun bir bireyi olduğu için "eşit", ama Gökşen'in babası, emekli Hasan olma özelliğiyle diğer bütün insanlardan ve Hasanlardan "farklı" bir kişi. Farklılık modern öncesi toplumlarda kutsal arka plandan dolayı doğal, bireyin doğuştan getirdiği mutlak kalite ve de değiştirilemez sonsuz bir nitelik olarak algılanırken, günümüzde farklılık, yaşam alanının rasyonelleşmesi nedeniyle evrim ve eşitlik kavramıyla birlikte düşünülmektedir (Luhmann, 1997: 22, 336, 634-640, 668; 708-710).

Bireysel ve fonksiyonel düzlemde statü, görev, rol, eylem, kimlik ve kişiliğin birbirinden ayrışması bu yeni değerlendirmenin en önemli sonuçlarındandır. Artık doğuştan atfedilmiş pozisyonlar değil, öğrenilmiş beceriler, kazanılmış haklar ve bunların kurumsallaştırılması daha önemli olmaya başladı. Birey bizzat kendisinin toplumda kazandığı, hak ettiği özellikleriyle anılmak istiyor. Fikirsel olarak her şeyin değiştiği prensibinden de yola çıkılarak bu transformasyonla birlikte kimliğe ve kişiliğe dair özellikler, aidiyetler ve roller önceden belirlenmiş, net, belli bir zaman dilimiyle sınırlandırılmaya başlandı. Özgürlük de artık sadece ahlak felsefesinin bakışıyla ve bireyin kabiliyeti olarak değil ama aynı zamanda Adam Smith ve Karl Marx gibi iktisatçıların da sayesinde ekonomik gelişim, katılım, (genel) çıkarların kurumsallaştırılması ve rasyonelleşme gibi kavramlarla anılmaya başlandı. Bu devinim sayesindedir ki günümüzde her insan birden fazla rolü edinebilir; çocuk, öğrenci, işveren, çalışan, memur, avukat, torun sahibi, emekli ve yaşlı olmak gibi, birey doğuştan gelmeyen kimi yeni özellikleri edinebilir ve (yeniden) kaybedebilir. Bu, belirleyici aidiyetler için de geçerli; yani bir yandan Alman ve aynı zamanda Yahudi, Türk, eşcinsel, siyahi ve de laik olmak öte yandan örneğin önce erkek, sonra kadın, daha sonra her iki rolü birden üstlenmek artık ne yadırganan tercihler ne de 
yadırganmasına izin verilen kimliklerdir. Bu dönüşümün yaşam alanında toplumun geniş tabakaları tarafından kabul görmesi sayesindedir ki örneğin eşitliği artık doğal koşullarda var olan bir gerçeklik değil ama modern hukukun gücüyle hayatta kendisini yeniden yenilemesi gereken kamusal iletişim biçimi olarak gözlemleyebiliyoruz.

\section{Çoğulculuk ilkesi ve Onun Üç Temsilcisinin Önerileri}

Bu perspektiften baktığımızda özellikle moderniteyle beraber özgürlük, demokrasi, hukuk ve eşitlik gibi temel felsefi kavramlar bir yandan bireysel tercihlerin, etik anlayışların ve kimliklerin birbirine yakınlaşmaları, birbiriyle karşılaştırılabilirlikleri gibi sosyolojik gerçeklikleri, diğer yandan da bunların artık normatif olarak farklılık kavramıyla değil de çoğulculuk fikri üzerine oturtulmaya başlandığını tespit etmekteyiz. Çoğulculuk felsefi ve tarihsel olarak farklı etnik ve/veya etik grup kimliklerin, aidiyetliklerin barış içinde aynı yerde, kamusal alanda varlığının kavramsallaştırılmış halidir. Bundan dolayı Hobbes özgürlükten bahsederken, dini kimliklerin kamudaki özgürlüğünü kasteder. Hobbes'unn Leviathan'daki en büyük amacı mezhep savaşlarına son verilmesi önerisidir. Bununla birlikte, dini kimlikler burada her ne kadar savaşa sebebiyet veren gerekçe olarak karşımıza çıksalar da onlar özelliklede ilk dönemlerinde krallıklar tarafından kan bağı prensibi üzerine sunulan kimliklerden daha ileridedirler. Sosyolojik olarak da dinler krallıklardan özgürleşmek isteyen bireylere hem farklı fikirler, çıkarlar ve hem de farklı yaşam biçimlerini temsil edebilmeleri özelliklerinden dolayı evrensel olma potansiyeli taşıyan edinilmiş kimlikler sunabildiler. Dini kimlikler sayesindedir ki, edinilmiş, yani bireyin kendi özgür iradesiyle seçtiği dini aidiyetlikleriyle birlikte artık sadece doğuştan gelen değil, istenmiş ve hak edilmiş kimlikler de kamusal alanda tartışılmaya, sunulmaya ve de kendisini yenilemeye başlamış bulunmaktadır. Bu ise kimliklerin, aidiyetliklerin birbiriyle sadece karşılaştırabilmesini değil ama aynı zamanda birbiriyle yarışabilmesinin de ortamını oluşturdu.

Bu yeni durum sivil toplum, fikir özgürlüğü ve çoğulculuk kavramlarıyla betimlenmektedir. Bunlar ve özellikle çoğulculuk moderniteyle beraber olumlu olarak sunulmakta ve anlaşılmaktadır ya da böyle anlaşılmakla birlikte, çoğulculukla bir araya gelince kimi yeni sorunların ortaya çıkmasına da yol açmıştır. Çoğulculuğu aynı alanda birden fazla doğrunun, iyinin, güzelin ve adilin varlığının kabul edilmesi olarak alırsak, özel yaşam ve kamusal alanın iç içe geçmesi ve bunun da kabul edilebilir bir norm olması halinde hangi doğrunun, iyinin, güzelin ve adilin bağlayıcı olarak kabul edileceği sorusu akla gelmektedir. Örneğin neden $X$ toplumunun anayasasını A, B, C, D değil de E'nin adalet anlayışına göre düzenlememiz gerekiyor? Bu soruya hangi kurumun hangi adalet kuramına, normuna göre bağlayıcı bir yanıt verilebilir? Bu sorular, sadece farklı anlayışların aynı ortamdaki varlığının ve bu birlikteliklerin kimi zaman iç savaşa meyilli olduğu gerçeğine değil ama aynı zamanda çoğulculuğun rasyonel bir projeye, yani bu farklılıkların benzerliklere dönüşmesi projesi ya da bunu 
engelleme projesine, farklıklarla barış içinde yaşama istemine dönüştüğünün de göstergeleri olmalıdır. Bu sorulara verilen yanıtları çoğulculuk ilkesinin birbiriyle zıt iki önemli temsilcisi olan Thomas Hobbes, Immanuel Kant ve de bu ikisinin sentezi olarak nitelendirilebilecek olan Jürgen Habermas'ın önerileri ışı̆̆ında irdelemek mümkün. Ilk iki düşünür arasındaki fark şudur; Hobbes çatışmayı barışı sağlama yöntemi olarak seçerken, Kant uzlaşıyı önermektedir. Habermas ise iki filozofun önerilerinden hareketle söylem topluluğuna aidiyeti önerir.

\section{Thomas Hobbes ve 'Leviathan'}

Hobbes, iç savaşların ve onlardan dolayı insan yaşamının bedhah (poor, nasty, brutish, and short) olmasının nedenlerini birbirine benzeyen ya da birbirinden farklı dini ve/veya diğer kimlikler üzerine kurulu yaşam biçimlerinin, aidiyetlerin, istemlerin ve çıkarların varlığında ya da onların temsilcilerinin herkes adına karar verememesinde aramaz (Hobbes, 1651: 78). Hobbes'a göre sorun çoğunluğun bu temsilcilerinden hiçbirinin özellikle çatışma dönemlerinde son sözü söyleyebilme yetkisine sahip olmamasıydı. Diğer bir deyişle, Hobbes sorunun kaynağının, çoğulculuk, farklıık, aidiyetlik veya özgürlük değil de eşitlik ilkesinde olduğunu düşünüyordu (Hobbes, 1651: 76-78, 94-96). Hobbes'a göre temsilcilerin hepsinin eşit olduğu bir yerde ancak herkes kendi fikir ve çıkarlarının genelleştirilmesi gerektiği konusunda uzlaşı halinde olabilirdi. Bu ise sürekli bir savaş hali anlamına gelir. Yenen ve yenilenlerin değiştiği, ama savaşın kendisinin hep sürdüğü bir denklemdir bu. Dolayısıyla Hobbes, çözümü eşitlik ilkesini özgürlük ilkesine uyarlamakta arar. Bu arayış onu Leviathan'a, yani toplumsal sözleşmeye dâhil olmayan, mantık biliminin araçlarıyla toplumsal sözleşmenin garantörü olarak tasarlanmış ama son tahlilde dini normlarla meşrulaştırılmış krallar kralına götürür (Hobbes, 1651: 196).

Bu kral hem diğer bütün insanlardan farklıdır hem de onların hepsinden daha özgürdür. Hobbes bunu bir yandan Aristoteles'in ahlak felsefesi kavramıyla, diğer yandan da dini, teolojik 'düşünce' yapısı sistemiyle biçimlendirilmiş aidiyet kavramı yerine, mantık biliminin metodu kullanılarak oluşturulan kişilik kavramından yola çıkarak, bireyin farklı sosyolojik koşullara rağmen aynı nedenlerle, yani 'çıkarlarıyla' yorumlamak gerektiği teziyle savunur. Hobbes döneminin genel bakışının tersine, farklılık ve onun üzerine kurulu kişilik kavramında yaşamdaki bütün değişikliklere rağmen hiç değişmeyen bir varlığı değil, bütün değişim ve dönüşümlere rağmen, kendisiyle aynı olma, aynı kalma becerisini anlıyordu (1651: 100-103). Kişilik kavramıyla Hobbes, ontolojik bir varlıktan değil, Heinrich'in (1979: 139) gözüyle bizzat bireyin kendisinin belirlediği varlık üretiminin sosyolojik koşullarından söz etmektedir. Kişilik bireyin, belirli kriterlerle farklı varlık koşullarında kendisiyle yüzleşmesidir. Nasıl ki bir devlet aynı anayasa tarafından yönetildiği sürece hep aynı kalabiliyorsa, birey de farklı koşullara rağmen hep aynı nedenlerle eylemini belirleyebilir ve bu anlamıla hep aynı kişi olarak kalabilir. Leviathan koltuğunda oturanın değişmesi ama Le-

106| ETKiLeşim | Yıl 4 |Sayı 7 |Nisan 2021 
viathan kurumunun değişmemesi gibi bir şey. Hobbes'un bu saptamasına göre kişilik, artık etik, aidiyet ya da bireyin bilinci ve/veya bilinç düzeyine göre varlığı iddia edilen değil ama kişinin içinde bulunduğu farklı zaman ve koşullara rağmen sürdürdüğü şey olarak tanımlanmaya başlandı (Henrich, 1979: 135). Birey ona verilmiş kimliği sayesinde değil, zamanla, yaşam alanında rüştünü göstererek otonomluk özelliği kazanır.

\section{Immanuel Kant ve Kategorik Zorunluluk}

Herkesin eşit olduğu ama sadece bir kişinin özgür olduğu Leviathan toplumunda savaşlar fiziki zor kullanılarak durdurulabilir, fakat hiçbir zaman tümüyle sonlandırılmaz. Çünkü barış sadece zorla sağlanamayacağı gibi, ancak özgür istemle kurulabilir ve uzun erimde de sürdürülebilir. Kant bu gerçeklikten yola çıkarak Leviathan yerine kategorik zorunluluk (Kategorische imperativ) kavramından türetilmiş özgürlük prensibi üzerine kurulu ve evrensel geçerliliği olabilecek bir öneride bulunur. Kant'ın önerisinin iki ayağı vardır: özgürlük ilkesi ve bilgi kuramı. Öneri, özgürlük ve çoğulculuk ilkelerinin epistemolojik olarak da birbiriyle barıştırılmaları gerektiği tezini içeriyor.

Kant, önerisinin ilk ayağı olan özgürlük ilkesini sosyolojik bir gerçeklikten çok otonom istemle birlikte ele alır. Kant'a göre birey zorunluluktan, aidiyetliklerinden, sübjektif veya objektif motiflerden, bireysel çıkarlardan veya kimi diğer 'rastlantısal' belirlemelerden değil, evrensel olma ihtimali olan bir kanundan yola çıkarak özgürleşebilir (1997: 33-74). Bunu yapabilen birey otonomdur, çünkü özgürlük kanununu bizzat kendisi belirlemektedir. Bu birey özgürdür, çünkü o bizzat kendi özgür iradesiyle bu kanuna uymaktadır. Kant ilkesel olarak bireysel, ulusal, dini ya da kültürel motiflerle değil ama evrensel gerçeklerle, onları anlayarak, kavrayarak ve bilgiye dönüştürerek eyleme geçen insandan yola çıkar. Bu kişi hem ulusal düzlemde toplumsal sözleşmenin bir parçası olan vatandaş olma özelliğinden dolayı kanunların objesidir, hem de insan olma hakkından dolayı kanun yapan evrensel kişidir. Kant kategorik zorunluluk ilkesinden yola çıkar; yani her birey kendi özgür iradesiyle evrensel olma ihtimali olan kanunla istediği kuralı, yaşam biçimini seçme, bu seçime göre toplumun diğer özgür bireyleriyle iletişime geçme ve de kurumlar geliştirme özgürlüğüne sahiptir (Kant, 1997: 60). Bunun pratik karşıı̆ı̆nı Ebedi Barış (Zum ewigen Frieden) kitabında önerdiği Birleşik Uluslar Hükümeti'nde aramaktadır.

Önerinin ikinci ayağı ise Kant'ın bilgi kuramıdır. Kant bu kuramında Aristoteles'in gerçekliğin, varlıkları doğru tanımlayabilmek olduğu görüşünden yola çıkarak evrensel gerçeklerin varlığı ilkesi üzerine kurar. Onun için kuram, kimi ampirik, pratik gerçekliklerden soyutlanmış genel evrensel geçerliliği olan prensiplerin birbiriyle ilintili bütünlüğüdür (Kant, cilt 11, 1977: 127). Kant'a göre tanıma, kavrama, anlama ve bilgilenme bu kuram aracılığıyla gerçeklerle doğru iletişime girmekle mümkündür. "Hakikat nedir? Hakikatın anlamı bilginin, nesnesiyle örtüşmesinden çıkar ya da bu varsayııır, ama insan her bilginin 
doğruluğunun genel ve kesin kriterinin ne olduğunu bilmek ister" (Kant, 1977: 101) $)^{2}$.

Kant, her aklıselim insanın, eylemlerini evrensel olma ihtimali olan bir ilkeden yola çıkarak anlamlandırabileceğine ve değerlendirebileceğine inanmaktadır. Peki bu ilkeler nerededir ve onlara ulaşmak nasıl mümkün olabilir? Kant, yaşamını bu soruya yanıt aramakla geçirdi denilebilir. Kant'a göre bilgi, a priori kavramsaldır. Bu bilgi mekâna, zamana, ilişkiye, değişime, şeylerin formuna ve niteliğine göre biçimlenir/oluşur. Bu bilginin kavramsallaştırıldığı alan ise felsefedir. Felsefe akılla, usla olayları ve olguları kavradığımız, anladığımız, anlattığımız ve şeyler hakkındaki bilgiye dönüştürdüğümüz alandır. Kant bu tezden yola çıkarak epistemolojisini homojenlik, özelleşme ve formların sürekli birlikteliği gibi üç temel kavram üzerine kurar (1977: 573-574):

\begin{abstract}
Akıl idrak'a kendi alanını şu yollarla hazırlar: 1. Daha üst türlerin altında bulunan çeşitliliğin benzerlik ilkesiyle, 2. Daha alt çeşitlerin temelinde yer alan benzerliklerin çeşitliliği ilkesiyle ve sistematik birliği tamamlamak için, 3- Ve buna bir de çeşitliliğin kademeli olarak gelişmesi yoluyla bir türden diğerine sürekli bir geçişi emreden tüm kavramların yasasını ekleyerek. Biz bunları homojenlik ilkesi, özelleşme ve formların yakınlaşması ve sürekliliği olarak adlandırabiliriz. Sonuncusu hem daha üst türlere yükseliş hem de alt türlere iniş esnasında, fikirdeki sistematik bağlantının tamamlanmasından sonra, ilk ikisini birleştirmekten oluşmaktadır; çünkü bütün çeşitlilikler birbiriyle akrabadırlar ve genel belirlemenin tüm kademelerinden geçerek tek bir en üst türden türerler. ${ }^{3}$
\end{abstract}

Kant'ın bu üç kavram üzerine kurduğu bilgi kuramı aydınlanma felsefesinin de temel taşlarını oluşturmuştur. Kant burada bir yandan tüm varlıkları çeşitliliklerine ve farklılıklarına göre sistematik olarak kategorize etmek, öte yandan da onları evrensel bir ilkeden hareketle mantığın genel yasalarının tümdengelim yöntemiyle elde etmek gerektiğinin altını çiziyor. Buradaki belirginlik ilkesi çeşitlilik ilkesine dayanır ve her tür için farklı özellikler, uzmanlıklar, varyasyonların bulunmasını talep eder. Yakınlık ilkesi ise tüm türler arasında sürekliliği aramayı öngörür. Kant daha üst cinsler arasında çeşitliliğin benzerliği ilkesini daha alt türler arasında benzerliğin çeşitliliği ilkesiyle bir arada düşünür. Yani akıl bir yandan yaşamın kanunlarını öte yandan ise yaşam alanındaki çeşitlilikleri, benzerlikleri, farklılıkları, eşit olanı çoğulculuk ilkesi gibi evrensel olma olasılığı olan bir ilkeyle bir araya getiren güçtür.

Aydınlanma felsefesi filozoflarının başında gelen Kant, bilginin tam da bu akıl sayesinde edinilebileceğine inanmaktadır. Bununla beraber Kant rasyonel bilginin, onun üzerine kurulu kavrayışın ve var olan sosyal-ekonomik altyapıdan farklı ama akılla, fikirle bezenmiş bir (anlam) dünyasının da olabilirliğine inanır. Kant, felsefesini en geniş anlamıyla bilim, idealizm ve bunların sentezi üzerine kurmaktadır. Kant, belki de bu yüzden bilimin çıplak gözle değil, doğal olmakla değil, deneylerle, gözlemle, metodik yöntemlerle yapılması gerektiğini savunmaktadır. Kant, bilimi insan ve dünya üzerine düşünceleri, istemleri,

Almancadan çevrilmiştir.

Almancadan çevrilmiştir.

108 | ETKíleşim | Yıl 4 |Sayı 7 | Nisan 2021 
bunların muhakemesi ve de muhakemenin evrensel bir teoriyle genel kanunlar haline getirildiği yer olarak görür. Aydınlanma bu kavramsal bilgi sistematiğinin sadece bilimle uğraşan bir azınlık tarafından üretimi ve kullanımı değil ama aynı zamanda onun toplumun geniş tabakalarının yaşam alanlarında da kabul görmesi, bu bilgiyle yaşamlarını düzenlemesi ve de kültürün, davranışın, eylemin bir parçası olmasıyla mümkün.

\section{Habermas ve Ahlaki Bakış Açısının Kuruluşu}

Jürgen Habermas gerek Hobbes'un 'zor' ve 'çıkar' gerekse de Kant'ın 'ikna' ve 'evrensel fikir' önerilerini bir yandan modernin ve çoğulculuğun etkin olduğu koşullara uyarlar, öte yandan da onların neden hem birbirlerini tamamladıklarını ve hem de onların önerilerinin etik yapıların değil ama adalet kuramlarının önermeleriyle gerçekleştirilebileceğini içeren yeni bir kavramsal çerçeve sunar. Aşağıda bu çerçeveyi öncelikle adaletin inşası başlığı altında tartıştıktan sonra, onun yukarıda dolaylı olarak değindiğimiz söylem topluluğuna aidiyet kavramına döneceğiz. Bu tartışmadan sonra Habermas'ın 'Söylem Teorisi'ni anlamak daha kolay olacaktır.

Kant'ın insancıl bakışı, Jürgen Habermas'ın hareket anıdır. Habermas dilbilimsel döngüyle (linguistic turn) hem etik ile bilimsel bilgi hem de nesnel "doğruluk" ile ahlaki gerçek, "hakikat" arasında bir ayrıma gidilmesi gerektiğini düşünür ${ }^{4}$. Etik bilgi ve bunun üzerine kurulu hakikat kuramları, geleneklere ve kültüre özgü günlük uygulamalara dayanırken, bilimsel bilgi önceden belirlenmiş koşullar çerçevesinde rasyonel yöntemlerle edinilir. Habermas bunu da göz önüne alarak epistemolojik teorisini geliştirirken Kant'tan esinlenir, ama daha çok da Karl Popper'in etkisinde kalarak hiçbir kanı ve bilginin yanılmaz olmadığı savının kavramlaştırıldığı 'fallibilizm' üzerine kurar. Ona göre, mantık, matematik ve dilbilgisi de yetkin yargı ve konuşmacıların sezgisel bilgisini yeniden inşa eden bilimlerdir (Habermas, 1991: 125). Habermas, bu epistemolojik temelde "tanıma" (Einsicht) ve "bilgisel kavrayış" (Erkenntnis) arasında iletişimsel bir ayrım yapar. Tanımayı, bir toplumda kendi tercihleri ve hedefleri olan bireylerin "epistemik gerekçelerle karar vermeyi" haklı çıkarabilme durumu olarak tanımlar (1996: 38). Habermas tanımayı kişinin akıl ve iradesiyle sosyal dünyadaki fenomenler hakkında paylaşılan etik bilginin nüfuz ettiği bir yansıma olarak görür. Ona göre tanıma içgörüsel ve sezgiseldir. Buna karşın bilgisel kavrayış teorize edilmemiş bilgiyi deşifre eder, bilinen bağlamlara yerleştirir, tutarlıı̆ına bakar ve bu şekilde eleştirel bakışa hazırlar (Habermas, 1996: 39). Burada bütün kanıların her cümlesinin geniş halk kesimleri tarafından kabul görmese bile, yüklem mantığında, formel kurallara göre formüle edilmiş temel cümlelerden türetilmişse geçerli ve doğrudur.

Fakat bir cümlenin formel mantıksal yüklem $>p<$ 'ye dayanması, doğru olması ve bilim camiası tarafından rasyonel nedenlerle 'kabul edilebilirliği', onun

Bkz.: (Wittgenstein, 1922) ve (Kegan ve Williams, 1985). 
sembolik iletişim normlarıyla biçimlendirilmiş yaşam alanında da 'kabul edileceği' anlamına gelmez. Bu ikisi arasındaki farkı 'herhangi bir bağlamda doğru' ve 'bizim bağlamımızda geçerli' ayrışımında görmek mümkündür (Habermas, 1996: 54). Habermas buradan da hareketle etik yargı içeren ifadelerle adalete dair formüle edilmiş cümleler arasında da bir ayrışıma gidilmesini önerir. Etik kuralların aksine adalet kavramından hareketle formüle edilmiş cümleler hem formel-mantık kriterlerine ve hem de yaşam normlarına uymalıdırlar (1996: 11-15). Habermas bu yargıya Yahudi-Hristiyan öğretisinin yaratıcı ve şifa geleneğindeki kavramsal yapıya bakarak varır. Buradan hareketle tanıma ile bilgisel kavrayış arasında ve dayanışma ile adalet arasındaki ilişkiyi tek bir iletişimin iki farklı yüzü olarak görür. Ona göre ahlak felsefesi, yaşam alanının rasyonalizasyonunu da göz önüne alarak bu ikili iletişim yapısını, onun mimarisini bilimsel eleştirel bakışla sorgulayıp onu modern çoğulculuk ilkesi ile yorumlarken bu tek iletişim ikiliğini post metafiziksel bir gerekçelendirme seviyesine çeker (1996: 21-22). Bununla birlikte ahlak felsefesi, Aristoteles (tanıma) ile başlayarak David Hume (işe yararlılık), Thomas Hobbes (sağduyu) ve Immanuel Kant (Kategorische imperativ) ile bir yandan bilgi kuramında ve diğer yandan da normatif varsayımlarında "ahistorik" olmaya başlamıştır; felsefe toplumlaşmış, toplumun gelenek, görenek ve ahlak yapısına göre davranan birey değil de, kimi rasyonelleştirilirmiş kriterlerle hareket eden bireyden yola çıkar. Habermas, Yahudi-Hristiyan geleneğine kıyasla en önemli değişimi, ahlak felsefesinin Kutsal Babanın Krallığında bir yaratılış doktrini ve iyileşme umudu yerine en genel anlamıyla irade (Wille) ve akıl (Vernunft) kavramlarını önermesi olarak görür. Akli olan, artık ya sağduyunun ışığında keyfiliğin (Willkür) sınırlarını belirleme yeteneği olarak ya da iradeyi tanıma yoluyla bene, benliğe bağlayan rasyonel motif olarak kabul edilir (Habermas, 1996: 23). Bu mantığa göre, aktör iradesini bilgelik, enstrümantal akıl, beceri, son tahlilde araçsal rasyonelliğiyle kamusal normlara bağlar.

\section{Yeni Bir Birlik Olarak Söylem Topluluğuna Aidiyet}

Burada sorulması gereken soru, Habermas'ın günümüzün çoğulcu yaşam formları göz önüne alındığında, yeni bütünlükçü birim olarak neyi önerdiğidir. Habermas bir yandan fallibilizmden hareketle epistemolojik düzlemde dini ve/ veya bilimsel bilgi yerine ama onları da içeren pratik ve/veya teorik söylemleri, öte yandan birlikteliklerin zorunluluğu fikrinden yola çıkarak ulusal, dini, cinsi kimlikler yerine, ama bu formları da içeren söylem topluluğuna aidiyeti öneriyor. Aşağıdaki tartışma bu önerinin içeriğine ilişkindir. Bunun için de öncelikle Habermas'ın "potansiyel olarak etkilenebilecek herkesin perspektifle uyumlu" (a) önerisini, bu önerinin aktörlerini (b), son olarak da onun birbirini tamamlayan iki söylem ilkesini (c) inceleyeceğiz.

(a) Habermas bir sosyolog olarak toplumun belirleyiciliğinden ve aynı zamanda bir filozof olarak belli bir toplumda ve o toplumun dili ve kültüründe sosyalleşmiş ve söylem (diskur) topluluğuna aidiyeti gönüllü, otonom istemiy-

110| ETKiLeşim | Yıl 4 |Sayı 7 |Nisan 2021 
le belirleyen bir bireyden hareket eder. Burada karşımıza ilk olarak çoğul birinci şahsın gözünden, hayat alanının üyeleri olarak bireylerin hayatlarını ortak normlarla nasıl yönlendirdikleri sorusu çıkar. Bizim için en iyisi nedir? Aynı soru, birinci tekil kişinin bakış açısından şu soruya dönüşür: Ben kimim, kim olmak istiyorum ve hayatımı nasıl yaşamak istiyorum? Etik sistemler bu soruya kolektif cevaplar verirler. Bununla birlikte, birey sosyalleşme, tanıma ve bilgisel kavrayışı sırasında mevcut gelenekleri, bilgi biçimlerini, soruları, yaşam şekillerini (a) yaşam alanında özel olarak edinildiğini, paylaşılmadığında ve haklı gerekçelerin varlığında ise "makul bir şekilde" değiştirildiğini de tecrübe eder (Habermas, 1996: 40). Diğer bir deyişle, etik sorularla toplumlar, onları temsil eden bireyler iyi ve birlikte bir yaşam tarzının ana hatlarını değerlendirirler. Ancak iyi ve birlikte yaşam bireyin cephesinde de otonom ve özgür yaşam anlamına gelmez. Bu nedenle Habermas yalnızca içinde formüle edilen önermelerin "potansiyel olarak etkilenebilecek herkesin bakış açısıyla uyumlu" (Perspektive aller möglicherweise Betroffenen) olan adalet kuramlarının genelleştirilebilirliğine izin verir (1996: 42). Ancak bu öneriler belli bir toplumun etiğinin ilerisinde bütün insanlığı bağlayabilme potansiyeli taşırlar. Bu açıdan bakıldığında, soru artık benim için/bizim için neyin iyi olduğu değil, genel olarak, her koşulda neyin iyi olduğudur. Bu soruya sadece gelenek-göreneklerden beslenen etik sistemleri değil ama mantık biliminin yöntemleriyle de çalışan hukuk ve adalet sistemleri de yanıtlar üretirler. Habermas (1996:43), adaleti iyi ve doğru olanı arama sistemi olarak görür ve hem geleneksel olarak etik sistemlerinin önermeleriyle kurumsallaştırılan dayanışma kavramı ve hem de bilgi kuramlarının üzerine inşa edilmiş hukuk sistemlerinin bağlayıcılığıyla ilişkilendirir.

(b) Burada sorulması gereken diğer bir soru ise kimin tek başına, genel bir prensibin penceresinden adil olana dair her soruyu, bütün koşullarda, tüm insanlar için aynı kalite, iyilik ve bağlayııılık derecesiyle yanıtlayabildiğidir. Habermas bu soruya genellikle filozoflar tarafından verilen yanıtların yaşam alanının çoğulculuğuyla birlikte daha umutsuz bir yeltenme olduğuna inandığından, bunu filozoflara değil de iletişimin genel yapıları çerçevesinde bizzat aktörlerin kendilerine bırakmayı önerir. Çünkü ona göre sadece ilgili aktörler, pratik müzakerelere katılanların bakış açısından, herkes için neyin iyi ve doğru olduğuna dair kabul edilebilir genel bir öneride bulunabilirler. Araçsal akılla hareket eden hiç kimse zorda kalmadığı sürece tanışmak istemediği birine kendi çıkarlarını göz ardı ederek onun yararına önerilerde bulunmaz. Bu nedenle, Hobbes'un Leviathan, Kant'ın "kategorik zor"u (Kategorische Imperativ) ya da John Rawls'un "tarafsız ahlaki bakış" açısı yerine, Habermas her insanın kendi kimliğine, kendi ilkelerine göre kendi seçtiği "topluluğa" ait olabileceği bir danışmanlık, müzakere ve de arabuluculuk uygulamasının yapısını önermektedir (Habermas, 1996: 42-45; Rawls, 1975: 38, 146, 174-185). Bu topluluk kavramıyla Habermas, bireyin doğduğu ve tercihlerini, değer yargılarını ve diğer soyut normlarını sorgulanmadan kabul ettiği somut topluluğu veya toplumu değil, söylem topluluğunu kastediyor. Bu ise herhangi bir iletişimsel yaşam biçiminde sosyalleşen herkesin ait olabileceği bir topluluktur. Söylem topluluğuna 
aidiyet topluluk ve toplum ikilemini geride bırakır.

Pratik düzlemde akla gelen ilk soru söylem topluluğuna aidiyeti kimin, nerede ve nasıl belirleyeceğidir; ikinci soru ise, bu topluluğun hangi ilkeye göre kurulup sürdürülebileceğidir. Habermas bu sorulara ancak bir yandan tanıma ve bilgisel kavrayış, diğer yandan adalet ile dayanışma ve de bunların da ilerisinde özgürlükle özerklik, otonomluk sağlayabileceğini düşündüğü söylem etiğiyle yanıt verileceğini ve de verilmesi gerektiğini düşünür. Bu varsayımı takiben Habermas söylem kuramının " $U$ " evrensellik ilkesini ve söylem kuralının temel önermesi “D”yi geliştirir. (c): Habermas'a göre, Kant'ın kategorik zor ilkesi ve/veya Rawls'un güçlü gelenekler ve kapsamlı doktrinler önerisi aşkın, transandantal iyiyi amaçlamaktadır (Rawls, 1975: 29-40; Habermas, 1983: 174; 1996: 101). Buradan bakıldığında $>D<$ tam da bu fikrin, istemin söylem-teorik önerisidir. Habermas bununla özellikle çoğulculuk ilkesinin beslendiği yaşam alanı, orada birçok yaşam formları ve çok sayıda bireysel motif ve kaynakların yan-yana, iç-içe olduğunun gerçekliği de göz önüne alındığında, ahlaki önermelerin bizzat söylem pratiğinden türetilmesi gerektiğini önermektedir. Söylem teorisinin etik önermesine (diskursethischer Grundsatz) (D) göre bir norm, pratik söylemin katılımcıları olabilme ihtimali olan bütün olası taraflarca onaylanırsa geçerlidir (Habermas, 1983: 132). Bu ilke ile Habermas ahlaki konuların Rawls'ın istediği tarafsızlık, önyargısız, "ideal gözlemci" değil ama bunların bilindiği ve uygun şekilde değerlendirilmesine izin verildiği bir "ideal konuşma" bakış açısını kazanmayı amaçlamaktadır. Bununla beraber, söylem etiğinin temel önermesi $>D<$ bu standartların hangi eylem önerileriyle yaşama uyarlanacağını tasarlayan evrenselleşme ilkesiyle $>U<$ beklenilen anlamı kazanır.

Habermas'ın evrenselleştirme ilkesi (Universalisierungsgrundsatz) $>U<$ 'ya göre her geçerli norm olası her bireyin çıkarlarını tatmin etmek için kendisine uyulmasından kaynaklanan sonuç ve yan etkilerin, bilinen alternatif düzenleme seçeneklerinin etkilerinden ziyade tüm paydaşlar tarafından "zorlamasız zorunluluk" ilkesi kabul edilebileceği koşulunu yerine getirmelidir (Habermas, 1983: 131; 1991: 123-134). >U< pratik uygulamalarından ziyade, eylem beklentilerinin veya talimatların uygulanmasında ortaya çıkan standartların gerekçelendirilmesi ile ilgilidir (Habermas, 1996: 59). Evrenselleşme ilkesi, ahlaki önermelerin geçerliliğini tartışan açıklayıcı söylemlerde kullanılır (Habermas, 1991: 137). Başka bir deyişle, evrenselleşme ilkesinin anlamı, idealize edilmiş koşullar altında tartışmalı bir durumun rasyonel değerlendirmesinin kimi evrensel iletişim koşullarınca (kamuya açıklık, potansiyel olarak etkilenenlerin dâhil edilmesi, eşitlik ve doğruluk gibi) gerçekleştirildiğinde, onların mutlaka tanınmasıyla eşdeğer olduğu gerekçesinde yatmaktadır (Habermas, 1996: 62).

\section{Ampirik Örneklendirmeler}

Hobbes'in tersine Kant, özgürlük kavramından yola çıkarak eşitlik ve çoğulculuk ilkelerinin de evrensellikte aranması gerektiğini savunur. Kant'ın hareket noktası var olan gerçeklik değil, olması gerekendir. Fakat soru var olması ge-

112 | ETKiLEşim | Yıl 4 |Sayı 7 |Nisan 2021 
reken gerçekliğe ulaşmada başvurulması gereken ilkelerin felsefenin dışında başka nerede ve nasıl bulunacağıdır. Kant evrensel filozof olma özelliğiyle yaşamını bu soruya yanıt aramakla geçirmiştir. Bununla beraber sadece Hobbes ve Kant değil ama Habermas da bu sorunun yanıtını felsefeye de yakın düşünce ve fikir sistemleri geliştiren ahlakın, dinin, etiğin ve de hukukun sunduğu kategorilerde ve de kategorileriyle aradı. Kant bu arayışı Hobbes gibi zor ve güçle değil de değinilen düşünce ve eylem sistemlerinin de ortak istemi olarak gördüğü sosyal barış ve adaleti katagorische imperativilkesinin süzgecinden geçirerek sağlamak istedi. Habermas ise 'kategorik zor'un yaşam bulduğu yeri bir yandan çoğulculuk, yani farklılılarla bir arada yaşama ilkesinin hayata uyarlanmasında, öte yandan da birlikte ve birlikteliğe dair pratik karar almada başvurulan uyuşma ve mutabakat yöntemlerinin de içeriklerini barındıran en evrensel olarak gördüğü söyleme aidiyette aradı. Teze göre söylem alanına aidiyet epistemolojik düzeyde anlama, tanıma ve bilgiyi, kavramsal çerçevede ise dayanışma ve adalet ile ilişkili olma durumudur. Bu ise tabii ki şu anda olmayan ama var olan koşulların idealize edilmiş halidir.

Yukarıda değinilen bu dört alanın (ahlak, din, etik ve hukuk) en temel ortak özelliği, onların da felsefe gibi somut gerçeklerle yetinmeyip, onları da idealize ederek olabilirliğine ihtimal verilen eylem kategorileri geliştirmeleri. Buradan bakıldığında sadece Hobbes ve Kant değil ama Habermas'ın kendisi de yukarıda formüle edilen 'nerede' sorusunun yanıtını hem felsefi ve formel mantık yöntemleriyle hem de ahlak, din, etik ve hukuk sistemlerinin yardımıyla aradı. Bu arka plana hayat alanının çoğulculuk ilkesi zemininden bakıldığında sosyolojik olarak sorulması gereken soru bizim birey olarak hangi şartlarda gerçeğe yakın bir dünya görüşüne sahip olduğumuz veya hangi şartlar altında haklıya, doğruya, iyiye ve güzele ulaştığımız değil, sadece entelektüel olarak değil ama toplumun bir üyesi olarak da dünyaya ve insana dair görüşlerimizi geliştirirken hep olanı, gözle görüleni, herkesin bildiğini bile neden idealize ettiğimizdir.

Aşağıda bu soruya kavramsal olarak Gılgamış'taki Tanrı imgesi ve Emile Durkheim'in dine yüklediği işleve bakarak yanıt vermeyi deneyeceğiz. Yöntemsel olarak geniş anlamıyla ampirik değil de, örneklendirme olarak aktörlerin dini kimlikler aracılığıyla kamudaki özgürlük ve eşitlik iletişimi incelenmektedir. Bu ise bizi artık neden dünyaya ve insana dair görüşlerimizi geliştirirken olanı idealize ettiğimiz sorusunun ötesine, yani bunu hangi kamusal alanda nasıl yaptığımız sorusuna götürecektir. Soruya Osmanlı, Avrupa ve Türkiye öznelinde halifelik, sekülerlik ve laiklik kurumlarına bakarak yanıtlar aranacakıır. Nasıl ki yazının girişinde özgürlük ile demokrasi arasındaki iletişim sosyal bilimlerle felsefe arasına keskin sınırlar koymaksızın incelendiyse, burada da yine aynı mantık kullanılarak felsefe ile sosyoloji arasındaki iletişim bazı ortak kuramlarda incelenmektir. Burada da amaç yine ampirik verileri felsefe ile sosyoloji arasındaki ilişkiden hareketle aynı anda yorumlamaktır. 


\section{Gılgamışve ölümsüzlük}

İnsanlık hep var olanın ilerisine gitmek istedi. Bu istek Gılgamış'ta yazılı hale getirildi. O dönem insanla Tanrı arasında bugünkü gibi keskin bir ayrım yoktu. Yarı insan yarı Tanrı, Gılgamış gibi üçte bir insan, ya da hem insan olup hem Tanrı olan ya da Tanrılıktan düşürülen varlıkların varlığı dönemin düşünce yapısına ters gelişmeler değildi. İnsanı Tanrı'dan farklı kılan, Tanrı'nın ölümsüz olmasıydı. Ancak Antik Yunan felsefesine göre her ne kadar ölümsüzlük Tanrılara aitse de sonsuzluk Tanrılara değil, insana ait (Arendt, 1992: 23-25). Tanrılar ölümsüzlükleriyle insanlar ise sonsuzluklarıyla övünürler. Tanrılar varlıklarıyla ölümsüzken, insanlar ölerek de sonsuzluğa ulaşabilirler. Zira insan dünyaya öyle eserler bırakır ki, bu eserler, eser sahibi öldükten sonra da hayatta kalmaya devam ederler. Bu ise insanların yaşadıkları dönemin çok ilerisinde var olabildiklerini; bu anlamda sonsuz olabileceklerini gösterir. Bunun bir sonucunu Tanrılar ile insanlar arasındaki iletişimde görebiliriz; Tanrılar, eylemlerinden dolayı kimse tarafından sorumlu tutulamazlar. Onlar sebep oldukları iyilik ve kötülüklerden dolayı ne yadırganır, ayıplanır ne de yargılanırlar. Buna insanların kudreti yetmez. Onlar ve eylemleri oldukları gibidirler. Buna karşın şairin de söylediği gibi, "hatasız kul olmaz", hatasız kul olunmaz. Hatasızlık değil, mükemmelliktir, mükemmel olabilme ihtimalidir insani belirleyen. Bu yüzden de iyiyi, güzeli, adili dolayısıyla kötüyü, çirkini, haksızı ve de yanlışı savunmak insana ait. Bu ayrışım farklılık ve eşitlik kavramlarına da yansır; farklılık dünyada ve insandan bağımsız olarak hep varken, eşitlik insanın ürünü. Tanrıların tersine insanlar sadece birbirileriyle olan benzerlikleriyle kalmıyorlar ama onlar aynı zamanda sosyal yaşamda, yaşadıkça, ürettikçe, iletişime girdikçe ve de son tahlilde hata yapmaya cesaret etikçe birbirileriyle olan farklılıklarını eşitliğe, eşitsizliğe dönüştürürler. Eşitlik doğanın, tanrıların lütfu değil, insanların etik ve/veya hukuk temelli başarısıdır.

\section{Emile Durkheim ve İdeal iletişim}

Durkheim, bu farklılığın pratik yaşama uyarlanmasında öncelikle insana hükmeden Tanrıların eylem veya iletişim arzusunu değil ama daha genel olarak insanla doğa arasındaki, insanın doğaüstü güçlerle ve de insanın doğaüstü arzularını fikirdaşlarıyla paylaştığı ilişki sistemini gördü. Durkheim'a göre insanın doğaüstü güçlerle etkileşimi, iletişimi ve ilişkisinde hem nesnel varlığın ilerisine geçmeyi ve hem de var olanı idealize etmeyi istedi ve öğrendi. Teze göre, insan var olan objektif ilişkilerin ilerisine gittikçe kendisini dünyanın ve evrenin bir parçası sayabilir. İnsanın mutlu olabilmesi, çevresiyle barışık yaşayabilmesi, var olanın ilerisine gidebilmesi ve bu anlamıla aşkın hale gelmesi, transandantaleşmesi bir yandan günlük ihtiyaçlarını karşılarken din, ahlak, hukuk ve ekonomi kurumlarına katılımı öte yandan da bu alanlarda var olan sosyal-ekonomik belirleyicileri toplumun bizzat kendi normlarıyla ama bireyin özerk istemi doğrultusunda yeniden üretmesi ve de biçimlendirmesiyle müm-

114| ETKíleşim | Yıl 4 |Sayı 7 |Nisan 2021 
kün (Durkheim, 1967:103-110; 129-132). Durkheim bu tezini hem modern ilişkilerden uzak halkların gelenek, göreneklerine ve dini ritüellerine bakarak, hem de modern toplumların kurumlarını yönlendiren hukuk sistemlerine ve onların din ve ahlakla olan ilişkilerini inceleyerek geliştirmektedir (Durkheim, 1981: III, IV, 296-310).

Teze göre, çalışmak, biyolojik ihtiyaçları karşılamak, okumak, çocuk yapmak vs. günlük yaşamın ilerisine giden birliktelikler ve bu birlikteliklerin organik iletişimi sayesinde öznel, hakiki ve aşkın anlamlar kazanırlar. Bu anlamlar ahlak, din, felsefe, sosyoloji, hukuk, eğitim vs. alanlarında kavramsallaştırılır. Kavramlar bu kültürel arka plandan dolayı insan üzerinden etkili olur. Onlar bundan dolayı bağlayıcıdır, dolayısıyla da kurumsallaştırılır ve toplumsallaştırılır, toplumun bilim ve diğer kurumları tarafından bir sonraki kuşağa aktarılıılar. Bu aktarım ise kültürel etkinlikler, kurallar, istemler ve beklentiler aracılığıyla, gelenek ve göreneklerde yeniden vuku bularak, hayata uyarlanır ve zamanla toplum, toplumun (ideal) temsilcileri tarafından genel bir gerçek olarak kabul görür (Parsons, 1937: VIII). Durkheim buradan bakarak dini, kavramsal düzlemde hem bu bilgi, ilişki ve iletişimin geliştirildiği ve hem de bunlarla uyum içindeki yaşam biçiminin oluşmasına ön ayak olan kurumsal alan olarak değerlendirir (Durkheim, 1981: 27-40). Din fonksiyonel olarak bir yandan insanın kendileşmesine, otonomlaşmasına, birey olmasına ve toplumun sadık, güvenilir, söz sahibi bir üyesi olmasına, diğer yandan da geçmişteki ve gelecekteki bütün insanlarla iletişime geçmesine vesile olan yapıdır. Din insanların hem en temel ihtiyaçlarını karşılarken hem de iyiyi, güzeli, adili ve de böyle idealleri yaşam alanında savunurken, onları isterken, düşlerken ki ahlaki eylem formlarından biridir.

Bununla birlikte iyiyi, güzeli, adili savunmak önce cenneti vadeden tek tanrılı dinlerde değil, araçsal, formel aklı kullanarak evreni kavramak isteyen felsefede dillendirildi. Güzel, iyi, adil nedir? Nasıl iyiye, güzele, adile ulaşılır? Bunlar felsefinin temel soruları. Ancak felsefe, özellikle de felsefenin bir kolu olan ahlak bilimi hem tarihsel olarak ve hem de çalışma yöntemi açısından teolojilere, dine hep yakındı. Felsefeden farklı olarak din her şeyin sebebini Tanrı'da, O'nun hikmetinde arar. Örneğin felsefenin temelini oluşturan "gerçek nedir, adalet nedir?" gibi sorular "Dinde var olan bütün bu problemler, kötülükler ve adaletsizlikler karşısında Tanrı neden hâlâ (bu dünyada) iyileri cezalandırıyor ve kötülükleri ödüllendiriyor?" sorusuna dönüştü (Nietzsche, 1954: 839-900; Weber, 1920, 613-744; 1988, 554). Din doğası gereği bu soruya var olanı eleştirel bir gözle değerlendirerek eylem kategorileri sunmak yerine, var olanı olduğu gibi kabul etmeyi, onda yaratanın hikmetini aramayı, son tahlilde ihtiyatla önerir.

Bu yakınlığı teolojik olarak bütün kitabi dinlerin birbirine benzerliğinde de görebiliriz. Tevrat, Incil ve Kur'an-ı Kerim dünyanın ve insanın oluşumuna dair benzer önerilerde bulunurlar. Yapısal olarak Tevrat ve Incil'den farklı olarak Kur'an-ı Kerim Allah'ın sözlerinin kaleme alınışının ispatıdır. Söylenen birebir 
yazılmıştır. Dolayısıyla değiştirilemez, aslından ayrı yorumlanamaz ve sadece yerine getirilir. Bundan da yola çıkılarak, İslami etik var olan kötülükler ve problemlere rağmen de Allah'ın kudretini, O'nun yasalarının haklılığını, O'nun düzenini ve adaletini savunmanın her Müslümanın bu dünyadaki temel görevi olarak belirler (23: 8)5. Bu etik anlayışa göre, müminlerin toplumdaki yerini Allah tayin eder. Allah'ın kanununa boyun eğmek, ona uygun bir yaşam biçimi belirlemek, var olanı korumak ve kollamak, Osmanlıların söylemiyle kanûn-u kadìm ilkesine uymak her kulun yapması gerekendir (87: 1). Insanların toplumdaki yerlerini iş, özveri, bilim, teknik gibi dünyevi koşullar, ya da eşitlikçi talepler değil, bizzat Allah'ın kendisi dünyevi neden-sonuç ilişkisinden bağımsız olarak belirler. Dolayısıyla da Allah'a sadece günahkârlar O'na, O'nun tarafından toplumda öngörülmüş, lütfedilmiş yerlerinden dolayı isyan ederler. İnsanın bu dünyada, toplumdaki yeriyle mutlu olması, O'na şükretmesi ve O'nu bütün gücüyle savunması, Allah'ın kanunlarına, O'nun hikmetine saygısının, güveninin ve de O'na olan güven ve itaatin bir göstergesidir. İnsan bunu Allah'ın ihtiyacı olduğu için değil, bizzat kendisinin bu dünyadaki huzuru, özgürlüğü için yapmalı (3: 17; 4: 40; 10: 44; 3). Mutluluk ve/veya onunla eş değer olarak görülen özgürlük var olan gerçekle yetinmenin ilerisinde olanda, yaşanılanda Tanrının öngörüşünü, hikmetini, hiddetini ve de belirleyiciliği görerek O'nu hatırlama ve O'na şükretme kabiliyetidir (16: 52; 24: 51-52; 55: 8). Adalet ise var olan bütün kötülüklere rağmen Allah'ın kudretini, O'nun yasalarının haklılığını, O'nun düzenini ve de bizzat O'nun varlığını savunmaktır (57: 25).

Fakat i̇slamiyet özellikle devlet anlayışıyla diğer kitabi dinlerden farklıdır. Hazreti Muhammed isa'dan farklı olarak ne yaratanın oğlu ne de sadece Peygamber. Hazreti Muhammed hem ordu komutanı, hâkim ve devlet başkanıydı ve hem de 'insanlığı' i̇slam'a, yani doğruya, barışçıl, iyi ve adil olana götüren ilk ve son Peygamberdir. O ilktir, çünkü O sadece yaratanın çocukları olduklarını iddia edenlerin değil, hiçbir fark gözetmeksizin herkesin Peygamberi. O son, çünkü O'nda doğru, gerçek ve adalet son halini almıştır. Bununla beraber, Kur'an-ı Kerim'den farklı olarak islami hukuk Hazreti Muhammed'in vefatından sonra da geliştirildi. Fethedilen topraklardaki kanun, kural ve gelenekler var olan i̇slami hukuk anlayışına adapte edildi. Osmanlı daha da ileri giderek Kanuni Sultan Süleyman önderliğinde i̇slami etik ve hukuktan bağımsız kanunlar geliştirdi ve bunu ise özellikle toprak reformunda hayata uyarladı. Yani bir yandan değiştirilemez ahlaki belirlemeler, öte yandan ise değişen yaşam alanı ve hukuk sistemi çıkarların kurumsallaştırıldığı alanda birbirileriyle iletişim halinde olan bir bütünlüğe kavuşturuldular.

Bu gelişme bir istisna olarak kalır. Buna karşın yukarıda bahsini ettiğimiz benzerlik ve farklılığın inananlar için günlük yaşamdaki pratik karşıı̆ı̆ı Allah'ın ilahi kanunlarının yeryüzündeki temsilcisi olan Peygamberin ve Halifelerin bizzat kendilerinin koyduğu kurala, kanuna sorgulamaksızın itaattir. Soru bu kuralın Şeyhülislamın, Sultanın veya diğer isimlerle adlandırılan devlet liderleri içinde geçerliliğini koruyup korumadığıdır. Birinde eylemi belirleyen ilke-

Kur'an-ı Kerim'in sureleri için bkz.: https://koransuren.com/.

116| ETKiLeşim |Yıl 4 |Sayı 7 |Nisan 2021 
ler eşitlik, özgürlük ve adalet, diğerinde ise farklılık ilkesi üzerine inşa edilmiş kardeşlik ve de dayanışmadır. Yönetenin, Peygamber ve Halifeler döneminde olduğu gibi Allah'ın yeryüzündeki temsilcisi olarak görüldüğünde, doğruyu/ yanlışı, iyiyi/kötüyü, haklıyı/haksızı, güzeli/çirkini vb. sadece o belirler, o bilir, denmiş olur. Son durumda, hak, hukuk, adalet bir yandan, bilim, sanat, iyi ve güzel diğer yandan Şeyhülislamın, Sultanın kardeşleri için belirlediğidir. Dolayısıyla da onun söyledikleri kanun, yaptıkları ise sadece Allah'ın ilahi kanunun icrasının birer örneğidir. O yanlış yapmaz. Bu yüzden de ceza hukuku veya sivil hukuk Sultanın belirledikleri, onun dünya ve insan anlayışına uygun olan kurallar silsilesidir.

Bu gibi gergin yapıdan dolayı Müslüman toplumlar, devletle din arasında bir ayrışma yerine siyasetin dine ve dinin ise siyasete hep müdahalede bulunduğu sistemleri seçti. Bu müdahale sürecinde de müdahaleleri iletişime dönüştürmek için çeşitli modeller geliştirildi. Örneğin Suudi Arabistan hâlâ halifelik sistemi ile yönetilir. İran ve geleneksel olarak Şiilikte ise devlet lideri bir memur işlevindedir. O Mehdi geri gelinceye kadar devleti doğru yönetmekle görevlidir. Yanlış yapabilir ve büyük hatalar yaptığında onu al-aşağı etmek her Müslümanın görevidir. Bu yüzdendir ki İran'da devrimler Fransa'daki protestolar gibi sistemseldirler. Ancak bu farklılıklara rağmen, kamu alanının bu i̇slami hukuk ve kurallar tarafından şekillendiği toplumlar çoğulculuk yerine tek merkezliliği ve kabiliyet yerine ise yönetene fiziki ve düşünsel yakınlıkla ve de böyle yakınlıkların iletişiminin belirlemesi üzerinden biçimlenirler. Yapılması ve beklenmesi gereken bellidir. Ama bu belli olanı hem çok az kişi bilir hem de onlara nasıl ulaşılacağı hakkında sadece seziler, söylentiler ve de manidar iddialar var. Buna karşın ilahi gücün yetkisiyle değil de farklılıkların örneğin çoğulculuk, evrensel eşitlik ilkesi etrafında birliktelik ideali üzerine kurulu kamu alanında hata, yanlış, eksik yapmak dolayısıyla da daha iyiyi, güzeli, doğruyu ve adili bulmak hep mümkün. Böyle toplumlarda siyaset sadece kardeşlik, aidiyet değil ama beceri, bilgi, çıkar, fikir ve de bunların kurumlarla olan iletişimi üzerine kuruludur. Dolayısıyla böyle toplumlarda demokrasinin araçları olan seçme ve seçilme eylemi bir emir, belirlenmişliğe veya ilahi vahiye verilen yanıt değil, tersine günlük yaşamı iyileştirmek üzere bütün bireylerin birbiriyle yarışabilmesini sağlayan araçlardır. Bireylerden kul ya da inanan değil ama vatandaş olma özellikleriyle, kamudaki eylemleriyle bu yapıyı fikirleri ya da çıkarları doğrultusunda ama son tahlilde özgür iradeleriyle belirlemeleri beklenir.

\section{Avrupa ve Osmanlı}

Bu kültürel ve yapısal bakış Avrupa'daki örnekleriyle karşılaştırıldığında daha bir berraklaşır. Buna şu tespiti yaparak başlayabiliriz; Avrupa ne adalet anlayışını, hukuk sistemini ne de demokrasi geleneğini Hristiyanlık dini üzerine kurdu. Avrupai sistemde Antik Yunan felsefesi üzerine kurulu demokrasi deneyimi ve Roma hukuku ilkeleriyle geliştirilmiş hukuk sistemi tam da Habermas'ın Yahudi-Hristiyanlık dini ile ahlak felsefesi arasındaki iletişime dair tespitindeki tez 
gibi bir bütünün iki ayrı bileşeni şeklinde sürekli bir iletişim halindedir. Her alanın işleyişi bizzat o alanın uzmanları tarafından belirlenen ilkeler ve o alandaki aktörlerin en geniş katılımı ilkeleri üzerine kuruludur. Doğru, gerçek veya haklı olan Tanrı'nın, din liderlerinin ya da hükümdarın belirlediği değil, alanın temsilcilerinin, örneğin hukukçuların geliştirdikleri ilke ve kurallar ışığında verilen kararlardır. Bu, Avrupa'da bilimin, sanatın, hukukun ve de ekonominin birbirinden ayrışması ve özerklikleriyle birbirileriyle iletişime geçmelerinin önünü açmıştır. Aşağıda bu farklılığa çoğulculuğun, eşitliğin ve özgürlüklerin en önemli kurumlarından olan üniversitelere bakılarak incelendikten sonra, önce Osmanlı elitlerinin modernleşmeye ayak uydurmak için nasıl din ve devlet ilişkilerini yeniden belirlemek istediklerine bakılacak; sonra da bu Avrupa'daki elitlerin tavrıyla karşılaştırılacaktır.

Söz konusu olan, siyasetçilerin topluma Amerikan ve Fransız Devrimleriyle önderlik ettikleri ve iş adamlarının ekonomiyi Newcomen'ın (1663-1729) buharlı motorlarıyla yeni bir dünyaya taşıdıkları dönem. Galileo Galilei (15641642) teleskopla ve deneyle yeni bir bilim standardı belirledikten sonra, iyi gözlem artık sezgiyle mümkün değildi (Chalmers, 1999: 22, 27-40, 163-165). Antik Çağ'da olduğu gibi Tanrıların hâkimiyetindeki doğaya çıplak gözle değil de bizzat insan yapımı olan merceklerle, gözlüklerle gerçeğe, güzele ve iyiye bakılmalıydı. Üniversiteler tam da bu fikrin kurumsallaşmış alanlarıdır. Antik çağın öğretmen ve öğrenci camiası, yönetenlerin diyalog yeri olarak bilinen okul kurumu önce manastırlar içinde etik bir toplumun gerçeklerini öğreten okul ve daha sonra yetenekli her elitin bilgiyi, kavramsal, ilkesel bakışı, rasyonelliği vb. öğrendiği ve üretebildiği Humboldt Üniversitelerine evrildiler. Burada bilim insanları olgulara Galileo'nun deney ilkesine uygun olarak en iyi koşullar altında yaklaşır, üretir ve eleştirirler (Habermas, 1986).

Yine yaklaşık aynı dönemde hayaller ülkesinde Amerika Birleşik Devletleri'nde, hem manastır ve Kant'ın evrensellik anlayışına uygun hem de Galileo sistemini yerine getiren pratikle, deneylerle ve teori olmaksızın da bilgi üretebilen üniversiteler ortaya çıkar (Parsons, 1951: 226-233; Parsons ve Platt, 1973). Din liderleri, iş adamları, akademisyenler ve diğer aktörler bilgi üretimi, sistematiği ve çoğaltma organizasyonu olan üniversiteleri kurmaya ve yönetmeye başlarlar (Stichweh, 1994: 246-277). Artık herkesin, Wilensky'nin (1964) saptamasına göre profesyonellik olanağı ve Schelsky'nin (1963) değimiyle de özgürlükle yalnızlık arasında bir seçim zorunluluğu vardı. Buna karşııık 16. yüzyıl Osmanlısına kadar varlıklarını koruyan medrese ve üniversiteler 1800'lere gelindiğinde yok olurlar (ihsanoğlu, 2004: 46). illk dönemin primus inter pares (eşitler arasında ilk/önder) ve çoğulculuk anlayışı tek merkezli ümmetçiliğe dönüştükçe, felsefe, matematik ve akılcılık yerine mezhepsel çatışmalar, kadercilik ve de milliyetçilik alır başını gider. Avrupa Rönesans, Aydınlanma, Endüstri Devrimleri ve katılımcı demokrasilerin gelişimine tanıklık ederken ve Avrupalılar bütün zorluklara rağmen özellikle de şehirlerde modern hukuk, ticaret, sözleşme, örgütlenme özgürlükleri ve bu çevrelerin önderliğinde devlet ve dinden özerk, kendine has ahlak ve iletişim araçlarına sahip bir kamusal alan

118| ETKíleşim |Yıl 4 |Sayı 7 |Nisan 2021 
oluşumu mücadelesi verirlerken, Osmanlıların yaşamları hâlâ "toprak, senin benim değil Allah'ındır" ilkesiyle yönlendiriliyordu.

Osmanlı elitleri Avrupa'nın gelişmişliğine din, hilafet, devlet ve toplum ilişkilerini yeniden düzenlemekle yanıt vermek isterler. Bunu ise öncelikle gelenekleri üzerinden yaparlar. Osmanlı'da, özellikle de kuruluşunda din ve devlet işleri ayrıydı. Hakan aynı zamanda Halife, din lideri değildi. Bunlar ayrı kurumlar ve ayrı kişiler tarafından temsil ediliyordu. Ancak halifeliğin Osmanlı'ya gelmesiyle bu durum değişti. O dönemden sonra sultan aynı zamanda halife oldu. Bu 19. yüzyıla gelindiğinde şeyhülislamlık kurumu ile yeniden değişime uğradı. Bu kurumum lideri aslında sadece bir bürokrat. Halifenin tersine Şeyhülislam sultanın siyasi politikalarının hayat bulabilmesi için dini, teolojik meşrutiyetini kurgulayan kurum. Halifenin teorik olarak sultana karşı çıkma ihtimali varken ve tersinden söylemek gerekirse sultanın halifeye karşı çıkma ihtimali yokken, şeyhülislam sultanın bir bürokratı olduğundan onun isteklerini yerine getirmekle mükelleftir (Karpat, 2009). Bununla birlikte özellikle de 19. yüzyılda bir yandan devletin demokrasiyle taçlandırılmaya çalışılmasına, ekonomi, hukuk ve eğitimi özerkleştirme çabalarına, diğer yandan da dini gelenek, görenek ve de alışkanlıklarla bu gelişmelere takoz olmayı, onları engellemeyi meşrulaştıran hareketlerin varlığına tanıklık ederiz. Devlet moderniteye geçiş adına bir dizi reform gerçekleştirme çabasındayken, bürokrasiyi din ve ahlak çerçevesinden çıkarma arzusundayken, dini kurum ve çevreler bu reformları engelleme peşinde, gelişmekte olan kamusal alanı da kutsallaştırma gayreti içerisindeydi.

Dini kurumların güce, devlet bürokrasisine olan bağılıkları artıkça, toplumdaki devrimci özelliklerini yitirirler, böylece devrimci gelişmelerin yorumunda da yetersiz kalmaya başlarlar. Bu yetersizlik, hazır olmama örneğin Avrupa'dan bilim insanı ve sanatçı transferi, Avrupa'ya öğrenci gönderme gibi tedbirlerle telafi edilmek istenir. Ancak ne gelen Avrupalılar ne de Avrupa'dan geri gelen Osmanlı öğrencileri toplumun gelişimine önderlik ederler (Mardin, 1969; Kahraman, 2010). Bu başarısızlığın en önemli nedenlerinden biri, her iki grubun da halktan kopuk, Batılı ve elitist olarak algılanmalarıdır. Bu mercekten bakıldığında, örneğin Gandi'nin Hindistan'da İngiliz sistemine karşı başarılı olabilmesinin en önemli nedenlerinden biri, Hindistan halkının İngiliz devlet ve toplum sistemiyle tanışık olmalarıdır. Buna karşılık Osmanlılar bir halk olarak hem kültürel hem de teknik bilgi birikimi açısından Avrupai ilişkilerden uzaktılar, onlara yabancıydılar. Dönemin önemli gazetelerinden iç̧tihad ve onun başyazarı Abdullah Cevdet bu uzaklık ve yabancılık durumunun nedenini Osmanlıların yaşamlarını devletin istemine rağmen bilim ve teknolojik bilgiyle değil de kültürel gelenek ve görenekler ve de dinsel doğmalardan oluşan alışkanlıklarla idame etme isteminde görür (Gündüz, 2008).

Oysa Avrupa'da nasıl ki Rönesans'a sanatçılar, Aydınlanma'ya da entelektüeller öncülük ettiler, dini reformlara da devlet, bürokratlar ya da bilim insanları değil bizzat kilise liderleri önderlik etti. Bu liderlerin halk tarafından desteklenmesinde kiliselerin malvarlığı, halkı gereksiz ve haksız vergilendirmeleri 
ve de kilise yöneticilerinin lüks yaşamlarının insanlar üzerindeki olumsuz etkileri önemli roller oynadı. Ama bunların da ötesinde daha da belirleyici olan, dinin teolojik olarak devletten ayrı olması ve de günlük yaşamın artık tutucu Katoliklikle idare edilemeyeceği yargısıydı. Katoliklikte inananların çalışması, üretime katılması kiliseye direkt bir yararı varsa iyiydi. Ancak genel olarak hem bilim hem de ticaret yadsınırdı. Fakat feodal toplumdan endüstri toplumuna geçişle bilime, ticarete, paraya, bankalara, sermayenin birikimi ve çıkar ilişkileri üzerine kurulu bir yaşam biçimine geçiş zorunlu hale gelmişti. Katoliklik bu üretim ilişkilerine karşı çıkarken, Protestan liderler bizzat bu ilişkileri dini temellere oturttukları için başarılı oldular. Protestanizm miskinliği, hayattan, üretim ilişkilerinden kopuşu değil, tersine akli olanı, doğruluğu, çalışmayı, ticareti, meslek edinmeyi ve karşılıklı güvenin sürdürülmesi üzerine kurulu yaşamı en büyük erdem saydı. Protestanlık kiliseye büyük paralar ödemeyi, şaşaalı kiliseler yapmayı, ya da genel olarak gösteriş üzerine kurulu yaşam sürdürmeyi değil, onun yerine geniş halk katmanlarının yaşam şekline uygun olan sade yaşamı önermektedir. Sadeliğin iyi, güzel ve doğru buna karşın masraflı, çarçur eden, israfçı bir yaşam biçiminin ise yanlış, dine, ahlaka, akla ters olduğunu savunur. Dolayısıyla da aşkın olmanın ve cennete gitmenin yolunun meslek yaşamında başarılı olmak, çalışmak, kazanmak, iyinin, güzelin yanında olmak, yani yeryüzünde güçlü olmakla ilişkilendirir. Protestanların mesleki başarı ve sade yaşam vurgusu toplumda bir yandan ticaretin, para ilişkilerinin, kapitalizmin, çıkar ilişkilerinin gelişmesine ve de dine uygunluğunun fikirsel yargısına, diğer yandan da bu yargıyla onların yeniden rasyonelleşmesine, kapitalizme uygun bir üst yapının, ona uygun etik, bilim, hukuk, kültür, eğitim sisteminin oluşması ve gelişmesine ön ayak oldu. Max Weber protestanizm ve modernizm tezinde işte tam da bu ilişkiler ağının dini, etik, ahlaki ve bilimsel, rasyonel normlarla yeniden düzenlenmesini analiz eder (Weber, 1920: 17-206). Teze göre Batı toplumları kapitalist üretim ilişkilerinin gerekliliklerini Protestanlık etiğinin ilkeleriyle barıştırabildikleri, bunu genel bir kültür haline getirebildikleri ve bireysel yaşam biçimlerini de buna uyarladıkları için başarılı oldular. Buna karşılık diğer bütün toplumlar üretim ilişkilerini bilindik dini istemler doğrultusunda düzenledikleri için başarısızlar. Her iki durum da teze göre bu dünyada başarı dinle, dini istemlerle ve dini istemlerin kültürel üretimiyle direkt ilişkili olarak tanımlanır.

\section{Sekülerleşme ve Laiklik}

Bu farklıığı sekülerleşme ve laiklik kavramlarında görmek mümkün. Türkiye Cumhuriyeti Devleti kuruluş döneminde toplumun dönüşümü özellikle sultanlıktan demokratik cumhuriyete, ilahi kanunlardan medeni hukuka, feodalizmden kapitalizme gibi ana hatlar üzerinde sürdürülmek istenir. Kurucu kadrolar kısa zamanda çok işler yapmak adına Osmanlı döneminde başlatılan reformları yeniden ama bu sefer devletin zoruyla hayata geçirmek isterler. Bunu ise Osmanlı'dan devralınan, i̇slami etik üzerine kurulu ve Şeyhülislamlık makamı etrafında geliştirilen dini politikalarla değil de kendi materyalist, Avrupa'dan 
etkilenilmiş dünya görüşleriyle yaparlar. Belki bir neden değil ama çözümleme olarak kurucu kadroların zoru seçmelerinin bir nedeni de dini ve dini iletişim biçimlerini medeniyete, moderniteye ulaşmanın önünde bir bakıma engel olarak görmeleridir. Fransız materyalistleri referans olarak alındılar. Yeni devletin yeni yöneticileri toplumu bilindik yöntemle dönüştürmenin mümkün olmadığına ya da en azından çok zor olduğuna kanaat getirmişlerdir. Gerçek, belki nesnel koşullar değil ama bu yargının bizzat kendisi devletin radikal eylemlere girmesinin meşru temeli olarak algılanır. Bu yenilenmenin nedenlerini anlama, meşruluk ve yöntem seçiminin en yoğun hali laiklik ilkesinde yansımaktadır. Laiklik, Osmanlı'daki sultan-halife hiyerarşisini de koruyarak, yeni devletin yeni insanlarını oluşturmanın yeni bir siyasi kurumu olarak yeniden dizayn edilir. Ve laiklik geleneksel dini kurum ve tavırlara karşı geliştirilmiş siyasi tutum ve/veya kamusal alanda baskın dini kimliğin yadsınması olarak algılandığı için, hep bir karşıtlık, bir ötekileştirmeyi üretmesi söz konusu olmuştur.

Bir şeyi doğru anlamanın bir yolu da, ona tersinden bakmaktan geçer. Bu noktadan hareketle laikliğin karşıtının ne olduğu sorusu sorulabilir. Türkiye'de laiklik çoğu zaman sekülerlik ile aynı anlamda alınır ve bu yanıyla da bazı çevrelerce aşırı dincilik veya dindarlık karşıtlığı olarak anlatıla ve anlaşılagelmiştir (Kuru, 2011; Demir, 2016: 452-472). Öncelikle aşırı dinciliğin ve dindarlığın karşıtının laiklik değil ama dinsizlik olduğunu belirtelim. İkincisi, laikliğin sekülerlikle eşit anlamda ele alınmasının ve devletin bütün dinlerle aynı mesafeyi kurma isteği olarak tanımlanmış olmasına karşın laikliğin tam da bu anlama gelmediğidir. Laikliğin, devletin bütün dinlerle aynı mesafede olması değil, dini kimliklerin kamudaki temsilini belirleme istemi olarak ele alınması daha doğru olur. Bu bilindiği için ve laikliğin Müslüman bir toplumda da kabul görme şansını artırmak adına, laiklik ve onunla ilgili sorunlar bütün toplumların moderniteye geçişinde karşılaşılan normal olgular olarak sunulmuştur. Bu ise kimi kurum ve anlayışların yasaklanmasıyla, kamudan uzaklaştırılması ve bunların yerine ise devletin yeni dini kimliklerin, siyasetin istemlerine uygun kurum ve çevrelerin desteklenmesi şeklinde yansımalara dönüşmüştür. Sorun, bir yandan yapılmak istenenle, yapılacağı sözü verilenle, gerçekte yapılan arasındaki büyük yapısal farklılıkların doğmuş olması, öte yandan da laiklik siyasetinden dolayı çıkan sorunlara çözüm getirmek yerine, bu sorunları modernitenin ve/ veya onunla eş değer tutulan sekülerliğin getirdiği 'evrensel' sorunlarmış gibi sunulması. Bu ise hem laiklikle sekülerlik arasındaki farkı görmeyi engellemekte, hem de toplumun büyük bir kesiminin bir bütün olarak moderniteye karşı çıkmaya başlamasıyla sonuçlanmıştır.

O halde burada vurgulanması gereken önemli bir nokta devletin belli bir dini kimliği, aidiyeti reddetmesi ya da desteklemesi değil ama kamusal alanda hiçbir dini kimlikle özdeşleşmemesi laiklik değil ama sekürlerlik prensibine ait ve de sekülerliğin birçok bileşenlerinden sadece birisi olarak görülmesidir. Sekülerliğin kilise malının devletleştirilmesi gibi siyasi zor kullanma bileşeni olmasıyla beraber, öncelikle din ile devlet ilişkilerinin farklı kurum, kural ve kişiler tarafından yönlendirilmesi 'fikri', 'istemi' değil, 'tecrübesi' üzerine kurulur. 
Bu ise yukarıda değinilen hukuk çerçevesi içerisinde kimi temel kültürel ve dini kurumların tarihsel gelişimiyle de ilgilidir. Yapısal olarak Avrupa eski Yunan geleneğinin bir mirası olan ev (oikos) ile devlet (polis), özel ile kamu alanını ayrıştırması organizasyonu üzerine kuruludur- Osmanlı oikos ve polis ayrıştırması yerine, bu iki alanı Sultanın evinde, hareminde ve Halife sıfatıyla tekleştirir. Sadece burada genel olan aynı zamanda özeldir. Avrupa'da toplumun kendisi de en başından beri en azından iki merkezli, din ve devlet yapısıyla süregelmiştir. Dini etik her iki alanla iletişim halinde olmasıyla beraber, hiçbir zaman onlarla aynı olmadı. Avrupa'da her iki taraf iletişimde kaldı, ama ayrışma kültürünün organizasyonu din, toplum ve devlet ilişkileri özelinde sekülerleşme olarak bilinmektedir.

Bu kültürel ve yapısal arka zeminden hareketle sekülerliği bireylerin dini aidiyetlikleri devletin değil ama toplumun desteğiyle kamusal alanda iletişim kurabilmeleri olarak tanımlayabiliriz. Buradan da dindarlığı devletin çokkültürlülükte savunulduğu gibi bütün dini aidiyetlikleri aynı derecede 'desteklemesi' ve dinsizliği ise dönemin Sovyetler Birliği'nde olduğu gibi devletin aktif olarak bütün dini kimliklere 'karşı çıkması' olarak belirleyebiliriz (Kymlicka, 2003). Bu ise bize laikliğin değil de sekülerliğin karşıtının gerçekten de dinsizlik, yani en radikal anlamıyla devletin, vatandaşlarını dini aidiyetlikleriyle kamuda temsil edilmelerini engelleme siyaseti olduğunu söylüyor. Sekülerliğin karşıtı dinsizlikse, o halde laikliğin karşıtını aşırı dindarlık değil de onun öteki yüzü olan halifeliği, yani devletin belli bir dini aidiyetliği diğer bütün dini aidiyetliklere karşı koyarak kamuda savunması olarak koymak daha doğru olur. Yani, kamusal alan tek bir dini kimlik tarafından belirlenmekte, bireylerin iletişimi de dini aidiyetlik üzerinden sürdürülmekte ve bu iletişim sisteminin bizzat kendisi devletin istemiyle ve kontrolünde yapılandırılıyorsa halifelik, laiklik, dinsizlik ve/veya dincilik devletin kamudaki dini kimliklerle olan siyaseti olarak karşımıza çıkmaktadır.

Buradan devam edersek, laiklik, halifelik ve dinsizlik devlet politikasının üç farklı versiyonu iken, sekülerlik yapısal olarak devletin topluma yukarıdan aşağıya değil, toplumun devlete alttan yukarıya doğru zorladığı kültürel kimliğin iletişimidir. Bu farklılıktan dolayı halifelik, laiklik ve dinsizlik devletin kamusal alana sürekli bir müdahalesini gerektirirken, sekülerlikte toplumun ahlaki, dini, hukuki değerlerini devlete karşı koruması ön plana çıkmaktadır. Bu anlamıyla da laiklik, hilafetçilik ve de dinsizlik sadece bireyin kültürel kodlarıyla edindiği kimlikler değil ama aynı zamanda devletin siyasi bir tercihi ve de devletin kamusal alanda dinsel kimliklerle olan ilişkisinin iletişim kodlarının biçimlenmesidir. Buna karşılık sekülerlik ta başından beri siyasi tutumdan, din karşıtlığından çok, vicdan özgürlüğü ilkesi üzerine kurulu bir tercihtir. Ancak, nasıl ki aydınlanma bilginin varlığı değil, onun toplumun geniş tabakaları tarafından kabul görmesiyle mümkün olmuşsa, sekülerleşme de aynı şekilde bireysel vicdani özgürlüklerin ilerisine gittikçe, yani genel olarak toplumun gelenek ve kurumlarında kültürel kodlamalarıyla mümkündür.

122| ETKiLeşim | Yıl 4 |Sayı 7 |Nisan 2021 
Kısaca, sekülerlik toplumun geniş tabakaları tarafından kabul görmüş felsefi görüş, kilise ve de devlete rağmen kamu alanında geliştirilmiş bir tutumken, laiklik bizzat devletin istemlerinden yola çıkılarak, devlet için vatandaşın devlete katılımı arzusu ve fikri üzerine kurulu siyasi bir tutumdur. Laikliğin halifelikten farkı ise, devletin hilafetin değil, hilafetin devletin bir kurumu olmasıdır. Halifelik var olanı korumak ve onun devamlılığı ilkesi üzerine kuruludur. Buna karşılık laiklik devletin henüz sahip olmadığı bireyin devşirilmesini amaçlar. Halifelikte devlet ve birey halife için varken, laiklikte birey devlet için yetiştirilmektedir. Sekülerlikte birey ve toplum devletten otonom olarak varlıklarını kurumsallaştırırlar, yani özerktirler. Onlar arasındaki ilişki farklıık değil, özgürlük kavramı üzerine kuruludur. İşte tam da bu yapısal farklılıktan dolayı din-devlet 'ilişkileri' Fransa ve Türkiye gibi laik ülkelerde devlet-toplum-birey ve kimliklerin dizaynı, Almanya, İsviçre, İngiltere ve Kanada gibi seküler toplumlarda toplum-birey ve devletin kamusal alandaki 'iletişimi'ne, Vatikan, Tayland, Suudi-Arabistan ve İran gibi dini devlet ve toplumlarda ise bir türlü içinden çıkılmaz biçimde ahlak-toplum-birey-devlet 'sorunu' olarak süregelmiştir.

\section{Sonuç}

Çoğulcu kamusal alanda dini kimliklerin özgürlük ve demokrasi iletişimi üzerine sürdürdüğümüz tartışmayı bir yandan insanların yaşadıklarını idealleştirme tezini yaşam alanının dönüşümü gerçekliğiyle birlikte düşünerek öte yandan ise sosyolojinin ve felsefenin bakışıyla şu iki temel sonuca vararak bağlamak mümkün; öncelikle yaşam alanının devinimiyle iletişim, özgürlük, demokrasi, kamu alanı, eşitlik, çıkarlar ve farklılık gibi temel kavramların kendileri de bir evrimden geçtiler. Geriye dönüp bakıldığında örneğin Aristoteles polis'in, Hobbes dini çevrelerin, Locke ve Rousseau topluma ait, varlıklı bireylerin ve Habermas ise söylem toplumuna ait her aktörün bilgi ve özgürlüğünden bahsettiğini iddia edebiliriz. Bu evrimi diğer tüm kavramlarda göstermek de mümkün. Bu noktada üzerinde durulması gereken şey, zamanla hem bu fikirlere yenilerinin eklendiği, aralarındaki iletişimin daha da arttığı, hem de onların yaşam alanındaki bağlayııılığını artırmak için gelenek, ahlak ve dinin yanı sıra bir de hukuk, sosyal bilimler ve felsefenin metotlarıyla soyut prensiplerin geliştirildiğidir.

18. yüzyıla kadar geliştirilen fikirler Kant'la beraber hem en genel kavramsal halini aldı hem de ulus-devlet ve üniversitelerle ideal bir formla belirleyici aktörlerin çıkarlarına uygun şekilde kurumsallaştırıldı. Üniversiteler bugün meşruluklarını ulus-devlet modelinin ilerisine taşıyarak ve farklılıklarıyla özerkliklerini korumak istiyorlar. Bununla beraber, ulus kendi içinde benzerliğin, eşitliğin, farklılığın, aidiyetin, kimliğin ve özgürlüğün hem bireysel hem de toplumsal içeriklerini de barındırıyor. Devlet ise o güne kadar var olan bütün kurumların en genelleştirilmiş, demokratikleştirilmiş ve özgürlükçü hali. Ve bir bütün olarak ulus-devlet köy, kasaba ve şehir gibi niceliksel birliktelikler bir yandan aşiret, kabile ve ümmet gibi niteliksel birliktelikler diğer yandan kimi evrelerden geçerek dünyamızın kimi yerlerinde mevcut olan demokratik 
adil devlet halini aldı. Fakat örneğin Benedict Anderson Imagined Cummunity ulus-devletin somut sosyolojik varlığına ve birliğine değil, fikirsel istemine ve birlikteliğine vurgu yapıyor. Ulus-devlet modeli tek bir bütünlük iması üzerine kurulmak istenmiş olmasına rağmen, toplumdaki farklılıkları nasıl fiziki zor kullanmaksızın birbiriyle iletişimde tutabileceği sorusuna cevap veremiyor.

Bu sorunun bir yansımasını laiklik kavramında görmek mümkün. Laiklik hem dinsizlik, dindarlık, halifelik, sekülerleşme gibi dini tercih odaklı aidiyetlikler, rasyonellik ve bilimsellik gibi epistemolojik kriterler hem de özgürlük, eşitlik, modernlik, demokratikleşme ve kamusal alanda iletişim gibi soyut kavramlarla bir arada düşünüldü. Bu çalışmada laiklik halifeliğin diğer yüzü ve sekülerleşmeden farklı bir olgu olarak işlendi. Sekülerleşme din liderlerinin önderliğinde ve alttan gelişen toplumsal bir devinim, halifelik, laiklik dindarlık ve dinsizlik ise devletin dine dair siyasi tutumları olarak tanımlandı. Laiklik hem bir toplumsal katılım ilkesi hem de yeni modern kimlik olarak anlaşılmaktadır. Türkiye Cumhuriyeti'nin kurucu kadrosu laikliği kurumsal düzlemde halifeliğin ve şeyhülislamlığın yerine diyaneti, kimlik olarak da dindarlık yerine laiklik ilkesini koyar. Ve bu yerine koyma eylemi hem dinle devlet işlerinin ayrışımı ve hem de modern, özgürlükçü, eşitlikçi, çoğulcu vs. yeni bir kimlik olarak sunulur. Oysa laikliğin tersine modern kimlikler devletlerin istemi ve sunumuyla değil, kültürel kodlamaların bireysel tercihlerle iletişimsel uyuşumuyla mümkündür. Bu ise bizi ikinci sonuca getiriyor: Sorun Osmanlı ümmet sisteminde olduğu gibi farlılıklarla bir arada yaşamada değil, demo'nun demoileştiği bir toplumsal gerçeklikte evrensel olduğu iddia edilen bir kanunla herkesi birlikte yaşamaya dâhil etmekte yatar. Epistemolojik düzlemde özellikle linguistic turn'le objektif doğru ile etik gerçek arasında bir ayrıştırılmaya gidildi. Bununla da hangi-norm sorusuna cevap aramanın ilk koşulunun eşitlikçi, özgürlükçü ve de adil olduğu iddiasındaki her etik kuralın, istemin ya da normun herkes tarafından anlaşılabilir bir cümleye dökülmesinden geçtiği savına gelindi. Buradan bakıldığında sorulması gereken soru, hangi koşullarda bir cümlenin (evrensel) doğruyu içerdiğidir. Bu epistemolojik soruyla öncelikle elde edilen şey, bir bütün olarak ahlak, din, etik dünya görüşü değil de artık sadece onlardan yola çıkılarak kurulan bir cümlenin doğruluğunun ya da yanlışlığının tartışma konusu yapıldığıdır. Bunun ilk koşulu ise her cümleyi bileşenlerine ayırmaktan geçer. Fakat matematik formüllerinden farklı olarak her etik içerikli cümle ancak ifade edildiği yaşam alanındaki kimi genel doğrular üzerinden anlam kazanır. Cümlenin bilişenlerinin anlaşılması ve içerdiği önermelerin kabulü ancak bu arka planla mümkündür.

Habermas bu yeni gerçekliği söylem kavramıyla temsil ediyor. Habermas 60'lı yıllarda Kamusallığın Yapısal Dönüşümü'nde kamuda uzlaşı koşullarının tarihsel-sosyolojik koşullarının gelişim seyrini, 80'li yıllarda yayımladığı iletişimsel Eylem Teorisi'nde sosyoloji ve felsefede geliştirilen teorilerle iletişimsel eylemin rasyonelliğini ve $90^{\prime}$ lı yıllarda geliştirdiği Söylem Teorisi ile de bu modellin evrensel iletişim yapısının moral teorinin sunduğu araçlarla savunmayı amaçlamaktadır. Teorisinin temel tezi, söylemin rızaya ve rasyonel onay vermeye açık, 
şeffaf erişim, eşit katılım, katılımcıların tartışmadaki samimiyeti, söylenenlerin doğruluğu gibi genel ilkeler garanti edilmiş ve önermelerin kendilerinin ise sadece "daha iyi olan gerekçenin zorlamasız zorunluluğu" (Zwang des besseren Arguments) ışığında gerçekleşmişse özerk iradeyle özgürlük arasında iletişimsel eylem işlevini üstelenebilecekleridir (Habermas, 1991: 132; 1999: 62). Söyleme aidiyetlik hem atfedilmiş kimlikleri hem de dindarlık, laiklik ve sekülerleşme gibi dini aidiyetleri aşan bir konsept. Bu yüzden söyleme aidiyetlik konsepti bunlar değil ama bunları da kapsayan çoğulculuk fikri üzerine kuruludur. Çoğulculuk ise bütün aidiyetliklerin iletişimsel varlık hakkı ilkesini içermektedir.

\section{Kaynakça}

Arendt, H. (1992). Vita activa oder Vom tätigen leben. München: Piper.

Aristoteles (1909). Nikomachische Ethik. Jena.

Chalmers, A. F. (1999). What is this thing called science. Indianapolis: Hackett.

Cheneval, F. (2015). Demokratietheorien zur Einführung. Hamburg: Junius.

Cheneval, F. ve Schimmelfennig, F. (2013). The case for demoicracy in the European Union. Journal of Common Market Studies, 51(2), 334-50.

Demir, A. (2016). Von Muhammad zu Atatürk: Eine analyse des türkischen pfades in die moderne anhand der theorie des kommunikativen Handelns von Jürgen Habermas. Zürich: Lit.

Durkheim, E. (1967). Soziologie und philosophie. Mit einer Einleitung von Theodor W. Adorno. Frankfurt a.M: Suhrkamp Verlag. rkamp.

Gündüz, M. (ed.) (2008). içtihat'ın içtihadı. Abdullah Cevdet’ten seçme yazılar. Ankara: Lotus Yayınevi.

Habermas, J. (1981). Theorie des kommunikativen Handelns, Band [cilt] II: Zur Kritik der funktionalistischen Vernunft. Frankfurt a.M: Suhrkamp Verlag.

------ (1983). Moralbewusstsein und kommunikatives Handeln. Frankfurt a.M.: Suhrkamp Verlag.

-- (1986). Die Idee der Universität-Lernprozesse. Zeitschrift für Pädagogik, 32(5). 703-718.

------- (1991). Erläuterungen zur Diskursethik. Frankfurt a.M.: Suhrkamp Verlag.

(1992). Faktizität und Geltung. Beiträge zur Diskurstheorie des Rechts und des demokratischen Rechtsstaates. Frankfurt a.M.: Suhrkamp Verlag.

(1996). Die Einbeziehung des Anderen. Studien zur politischen Theorie. Frankfurt a.M.: Suhrkamp Verlag. 
(2013). Strukturwandel der Öffentlichkeit. Untersuchungen zu einer Kategorie der bürgerlichen Gesellschaft. Frankfurt a.M.: Suhrkamp Verlag.

Henrich, D. (1979). 'Identität', Begriffe, Probleme, Grenzen. Marquard, O. ve Stierle (ed.), Poetik und Hermeneutik. Arbeitsergebnisse einer Forschungsgruppe VIII. Identität (133-186). München: Wilhelm Fink.

Hobbes, T. (1651). Leviathan or the matter, forme, \& power of a common-wealth ecclesiasticall and civill. St. Pauls Church-yard.

ihsanoğlu, E. (2004). Science, technology and learning in the Ottoman Empire: Western influence, local institutions, and the transfer of knowledge. Aldershot: Ashgate Variorum.

Kahraman, H. B. (2010). Türk siyasetinin yapısal analizi I-II. İstanbul: Agora Kitaplığı.

Kant, I. (1997): Werke in zwölf Bänden. Band [cilt] III, Band [cilt] IV, Band [cilt] VI, Band [cilt] XI. Frankfurt a.M.: Suhrkamp.

Karpat, K. H. (2009). Osmanlı'dan günümüze elitler ve din. İstanbul: Timaş Yayınları.

Kegan, P. ve Williams, B. (1985). Ethic and the limits of philosophy. Cambridge: Harvard University Press.

Kuru, A. T. (2011): Pasif ve dışlayıcı laiklik: ABD, Fransa ve Türkiye. İstanbul: İstanbul Bilgi Üniversitesi Yayınları.

Kymlicka, Will (2003). Multicultural citizenship: A liberal theory of minority rights. Oxford: Clarendon.

Locke, J. (1977). Zwei Abhandlungen über die Regierung. Frankfurt am Main: Suhrkamp Verlag.

Luhmann, Niklas (1997). Die Gesellschaft der Gesellschaft. Band [cilt] I. - Band II. [cilt] Frankfurt a.M.: Suhrkamp Verlag.

Mardin, Ş. (1969). Power, civil society and culture in the Ottoman Empire. Comparative Studies in Society and History, 11(3), 258-281. http://www.jstor.org/stable/178085.

Nietzsche, F. (1954). Werke in drei Bänden. Band [cilt] II. München: Carl Hanser Verlag.

Parsons, T. (1937). The structure of social action: a study in social theory with special reference to a group of recent European writers. New York: The Free Press.

------- (1951). The social system. London: Routledge.

-------- (1960). Pattern variables revisited: A response to Robert Dubin, American Sociological Review, 25(4), 467-483.

-------- (1968). Interaction: Social Interaction. International encyclopedia of the social sciences, Volume [cilt] VII. (429-441). New York.

Parsons, T. ve Platt, G. M. (1973). The American university. Cambridge: Harvard.

126| ETKíleşim |Yıl 4 |Sayı 7 | Nisan 2021 
Popper, K. (1992). Die offene Gesellschaft und ihre feinde. Band [cilt] I. Tübingen: JCB Mohr. mann.

Rawls, J. (1975). Eine Theorie der Gerechtigkeit. Frankfurt a.M.: Suhrkamp Verlag. (1998): Politischer Liberalismus. Frankfurt a.M.: Suhrkamp Verlag.

Rousseau, J. J. (1984). Diskurs über den Ursprung und die Grundlagen der Ungleichheiten unter den Menschen [Exorde]. Meier, H. (ed.) Diskurs über die Ungleichheit (Discours sur l'inégalité) (67-493). Paderborn: Ferdinand Schöningh. Reclam. (2003). Gesellschaftsvertrag oder Grundsätze des Staatsrechts. Stuttgart:

Sartori, G. (1997). Demokratie Theorie. Darmstadt: Primus.

Schelsky, H. (1963). Einsamkeit und Freiheit: Idee und Gestalt der deutschen Universität und ihrer Reformen. Hamburg: Rowohlt.

Stichweh, R. (1994). Wissenschaft, Universität, Professionen: Soziologische Analysen. Frankfurt a.M.: Suhrkamp Verlag.

von Beyme, K. (2007). Theorie der Politik im 20. Jahrhundert: von der Moderne zur Postmoderne. Frankfurt am Main: Suhrkamp Verlag.

------- (1999). Zivilgesellschaft - Karriere eines Modebegriffs. Ruperto Carola, 2.

Weber, M. (1920). Die protestantische Ethik und der Geist des Kapitalismus. Max Weber. Gesammelte Aufsätze zur Religionssoziologie, Band [cilt] I. (17-206). Tübingen: Mohr Siebeck.

(1988). Politik als beruf. V. J. Winckelmann (haz.) Max Weber. Gesammelte politische Schriften. Tübingen: Mohr Siebeck.

Wilensky, H. L. (1964). The professionalisation of everyone. American Journal of Sociology, 70(2), 137-158.

Wittgenstein, L. (1922). Tractatus Logico-Philosophicus. London.

Çıkar çatışması: Çıkar çatışması bulunmamaktadır.

Finansal destek: Finansal destek bulunmamaktadır.

Conflict of interest: There are no conflicts of interest to declare.

Financial support: No funding was received for this study. 